\title{
Foraminiferal community response to seasonal anoxia in Lake Grevelingen (the Netherlands)
}

\author{
Julien Richirt ${ }^{1}$, Bettina Riedel ${ }^{1,2}$, Aurélia Mouret ${ }^{1}$, Magali Schweizer ${ }^{1}$, Dewi Langlet ${ }^{1,3}$, Dorina Seitaj ${ }^{4}$, \\ Filip J. R. Meysman ${ }^{5,6}$, Caroline P. Slomp ${ }^{7}$, and Frans J. Jorissen ${ }^{1}$ \\ ${ }^{1}$ UMR 6112 LPG-BIAF Recent and Fossil Bio-Indicators, University of Angers, \\ 2 Boulevard Lavoisier, 49045 Angers, France \\ ${ }^{2}$ First Zoological Department, Vienna Museum of Natural History, Burgring 7, 1010 Vienna, Austria \\ ${ }^{3}$ Univ. Lille, CNRS, Univ. Littoral Côte d'Opale, UMR8187, LOG, Laboratoire d'Océanologie et \\ de Géosciences, 62930 Wimereux, France \\ ${ }^{4}$ Department of Ecosystem Studies, Royal Netherlands Institute for Sea Research (NIOZ), Yerseke, the Netherlands \\ ${ }^{5}$ Department of Biology, University of Antwerp, Universiteitsplein 1, 2610 Wilrijk, Belgium \\ ${ }^{6}$ Department of Biotechnology, Delft University of Technology, $2629 \mathrm{HZ}$ Delft, the Netherlands \\ ${ }^{7}$ Department of Earth Sciences (Geochemistry), Faculty of Geosciences, Utrecht University, \\ Princetonlaan 8a, 3584 CB Utrecht, the Netherlands
}

Correspondence: Julien Richirt (richirt.julien@gmail.com)

Received: 23 September 2019 - Discussion started: 1 October 2019

Revised: 6 February 2020 - Accepted: 10 February 2020 - Published: 20 March 2020

\begin{abstract}
Over the last decades, hypoxia in marine coastal environments has become more and more widespread, prolonged and intense. Hypoxic events have large consequences for the functioning of benthic ecosystems. In severe cases, they may lead to complete anoxia and the presence of toxic sulfides in the sediment and bottom-water, thereby strongly affecting biological compartments of benthic marine ecosystems. Within these ecosystems, benthic foraminifera show a high diversity of ecological responses, with a wide range of adaptive life strategies. Some species are particularly resistant to hypoxia-anoxia, and consequently it is interesting to study the whole foraminiferal community as well as speciesspecific responses to such events. Here we investigated the temporal dynamics of living benthic foraminiferal communities (recognised by CellTracker ${ }^{\mathrm{TM}}$ Green) at two sites in the saltwater Lake Grevelingen in the Netherlands. These sites are subject to seasonal anoxia with different durations and are characterised by the presence of free sulfide $\left(\mathrm{H}_{2} \mathrm{~S}\right)$ in the uppermost part of the sediment. Our results indicate that foraminiferal communities are impacted by the presence of $\mathrm{H}_{2} \mathrm{~S}$ in their habitat, with a stronger response in the case of longer exposure times. At the deepest site $(34 \mathrm{~m})$, in summer 2012, 1 to 2 months of anoxia and free $\mathrm{H}_{2} \mathrm{~S}$ in the
\end{abstract}

surface sediment resulted in an almost complete disappearance of the foraminiferal community. Conversely, at the shallower site $(23 \mathrm{~m})$, where the duration of anoxia and free $\mathrm{H}_{2} \mathrm{~S}$ was shorter (1 month or less), a dense foraminiferal community was found throughout the year except for a short period after the stressful event. Interestingly, at both sites, the foraminiferal community showed a delayed response to the onset of anoxia and free $\mathrm{H}_{2} \mathrm{~S}$, suggesting that the combination of anoxia and free $\mathrm{H}_{2} \mathrm{~S}$ does not lead to increased mortality, but rather to strongly decreased reproduction rates. At the deepest site, where highly stressful conditions prevailed for 1 to 2 months, the recovery time of the community takes about half a year. In Lake Grevelingen, Elphidium selseyense and Elphidium magellanicum are much less affected by anoxia and free $\mathrm{H}_{2} \mathrm{~S}$ than Ammonia sp. T6. We hypothesise that this is not due to a higher tolerance for $\mathrm{H}_{2} \mathrm{~S}$, but rather related to the seasonal availability of food sources, which could have been less suitable for Ammonia sp. T6 than for the elphidiids. 


\section{Introduction}

Hypoxia affects numerous marine environments, from the open ocean to coastal areas. Over the last decades, a general decline in oxygen concentration was observed in marine waters (Stramma et al., 2012), with an extent varying between the concerned regions. In coastal areas, oxygen concentrations have been estimated to decrease 10 times faster than in the open ocean, with indications of a recent acceleration, expressed by increasing frequency, intensity, extent and duration of hypoxic events (Diaz and Rosenberg, 2008; Gilbert et al., 2010). This is due to the combination of (1) global warming, which is strengthening seasonal stratification of the water column and decreasing oxygen solubility, and (2) eutrophication resulting from increased anthropogenic nutrient and/or organic matter input, which is enhancing benthic oxygen consumption in response to increased primary production (Diaz and Rosenberg, 2008). Bottom-water hypoxia has serious consequences for the functioning of all benthic ecosystem compartments (see Riedel et al., 2016, for a review). Benthic faunas are strongly impacted by these events (Diaz and Rosenberg, 1995), even though the meiofauna, especially foraminifera, appears to be less sensitive to low dissolved oxygen (DO) concentrations than the macrofauna (e.g. Josefson and Widbom, 1988). Many foraminiferal taxa are able to withstand seasonal hypoxia-anoxia (see Koho et al., 2012, for a review), and consequently they can play a major role in carbon cycling in ecosystems affected by seasonal low-oxygen concentrations (Woulds et al., 2007). Anoxia is often accompanied by free sulfide $\left(\mathrm{H}_{2} \mathrm{~S}\right)$ in pore and/or bottom waters (e.g. Jørgensen, 1982; Seitaj et al., 2015), which is considered very harmful for the benthic macrofauna (Wang and Chapman, 1999). Neutral molecular $\mathrm{H}_{2} \mathrm{~S}$ can diffuse through cellular membranes and inhibits the functioning of cytochrome $c$ oxidase (a mitochondrial enzyme involved in ATP production), finally inhibiting aerobic respiration (Nicholls and Kim, 1982; Khan et al., 1990; Dorman et al., 2002).

Lake Grevelingen (southwestern Netherlands) is a former branch of the Rhine-Meuse-Scheldt estuary, which was closed in its eastern part (riverside) by the Grevelingen Dam in 1964 and in its western part (seaside) by the Brouwers Dam in 1971. The resulting saltwater lake, with a surface of $115 \mathrm{~km}^{2}$, is one of the largest saline lakes in western Europe. Lake Grevelingen is characterised by a strongly reduced circulation (even after the construction of a small sluice in 1978) with a strong thermal stratification occurring in the main channels in summer, leading to seasonal bottom-water hypoxia-anoxia in late summer and early autumn (Bannink et al., 1984). This situation results in a rise of the $\mathrm{H}_{2} \mathrm{~S}$ front in the uppermost part of the sediment, sometimes up to the sediment-water interface.

These observations especially concern the Den Osse Basin (i.e. one of the deeper basins, maximum depth $34 \mathrm{~m}$; Hagens et al., 2015), which has been intensively monitored over the last decades, so that a large amount of environmental data are available (e.g. Wetsteijn, 2011; Donders et al., 2012). The annual net primary production in the Den Osse Basin (i.e. $225 \mathrm{~g} \mathrm{C} \mathrm{m}^{-2} \mathrm{yr}^{-1}$; Hagens et al., 2015) is comparable to other estuarine systems in Europe (Cloern et al., 2014). However, there is almost no nutrient input from external sources; thus primary production is largely based on autochthonous recycling (>90\%; Hagens et al., 2015), both in the water column and in the sediment, with a very strong pelagic-benthic coupling (de Vries and Hopstaken, 1984). The benthic environment is characterised by the presence of two antagonistic groups of bacteria, with contrasting seasonal population dynamics (i.e. cable bacteria in winter-spring and Beggiatoaceae in autumn-winter), which have a profound impact on all biogeochemical cycles in the sediment column (Seitaj et al., 2015; Sulu-Gambari et al., 2016a, b). The combination of hypoxia-anoxia with sulfidic conditions, which is rather unusual in coastal systems without external nutrient input, and the activity of antagonistic bacterial communities makes Lake Grevelingen a very peculiar environment. In the Den Osse Basin, seasonal anoxia coupled with the presence of $\mathrm{H}_{2} \mathrm{~S}$ at or very close to the sediment-water interface occurs in summer (i.e. between July-September). However, euxinia (i.e. diffusion of free $\mathrm{H}_{2} \mathrm{~S}$ in the water column) does not occur, because of cable bacterial activity (Seitaj et al., 2015).

Although the tolerance of foraminifera towards low DO contents and long-term anoxia (from weeks to 10 months) has been well documented for many species from different types of environments in laboratory culture (e.g. Moodley and Hess, 1992; Alve and Bernhard, 1995; Bernhard and Alve, 1996; Moodley et al., 1997; Duijnstee et al., 2003, 2005; Geslin et al., 2004, 2014; Ernst et al., 2005; Pucci et al., 2009; Koho et al., 2011) as well as in field studies (e.g. Piña-Ochoa et al., 2010b; Langlet et al., 2013, 2014), their tolerance of free $\mathrm{H}_{2} \mathrm{~S}$ is still debated. In the vast majority of previous studies, no decrease in the total abundances of living foraminifera (i.e. strongly increased mortality) was observed during anoxic events. Unfortunately, studies on foraminiferal response in systems affected by seasonal hypoxia-anoxia with sulfidic conditions are still very sparse. The few available observations are not conclusive, but they suggest that $\mathrm{H}_{2} \mathrm{~S}$ could be toxic for foraminifera even on fairly short timescales (Bernhard, 1993; Moodley et al., 1998b; Panieri and Sen Gupta, 2008; Langlet et al., 2014).

To our knowledge, all earlier studies show that the foraminiferal response to hypoxia-anoxia is species-specific (e.g. Bernhard and Alve, 1996; Ernst et al., 2005; Bouchet et al., 2007; Geslin et al., 2014; Langlet et al., 2014). However, this species-specific response generally follows the same scheme (usually decrease in density, reduction of growth and/or reproduction), with different response intensities. Duijnstee et al. (2005) suggested that oxic stress leads to an increased mortality and inhibited growth and reproduction. The suggestion of inhibited growth is supported by LeKieffre et al. (2017), who observed that the morphos- 
pecies Ammonia tepida (probably Ammonia sp. T6) showed minimal or no growth under anoxia. Conversely, Geslin et al. (2014) and Nardelli et al. (2014) suggested that, in the same morphospecies, reproduction was strongly reduced, but growth would not be affected by hypoxic and/or short anoxic events. Additionally, under low-oxygen conditions, some species are able to shift to anaerobic metabolism (i.e. denitrification; Risgaard-Petersen et al., 2006; Piña-Ochoa et al., 2010a), to sequester chloroplast (i.e. kleptoplastidy; Jauffrais et al., 2018), to associate with bacterial symbionts (Bernhard et al., 2010) or to enter into a state of dormancy (Ross and Hallock, 2016; LeKieffre et al., 2017).

The highly peculiar environmental context of Lake Grevelingen offers an excellent opportunity to study this still poorly known aspect of foraminiferal ecology.

The conventional method to discriminate between live and dead foraminifera uses Rose Bengal, a compound which stains proteins (i.e. organic matter). This method was proposed for foraminifera by Walton (1952) and is based on the assumption that "the presence of protoplasm is positive indication of a living or very recently dead organism". The author already noted that this assumption implied that the rate of degradation of organic material should be relatively high. Previous studies of living benthic foraminifera in environments subjected to hypoxia-anoxia were almost all based on Rose Bengal-stained samples (e.g. Gustafsson and Nordberg, 1999, 2000; Duijnstee et al., 2004; Panieri, 2006; Schönfeld and Numberger, 2007; Polovodova et al., 2009; Papaspyrou et al., 2013). However, foraminiferal protoplasm may remain stainable from several weeks to months after their death (Corliss and Emerson, 1990), especially under low dissolved oxygen concentrations where organic matter degradation may be very slow (Bernhard, 1988; Hannah and Rogerson, 1997; Bernhard et al., 2006). The Rose Bengal staining method is therefore not suitable for studies in environments affected by hypoxia-anoxia. Consequently, the results of foraminiferal studies in low-oxygen environments based on this method have to be considered with reserve. In order to avoid this problem, we used CellTracker ${ }^{\mathrm{TM}}$ Green (CTG) to recognise living foraminifera. CTG is a fluorescent probe which marks only living individuals with cytoplasmic (i.e. enzymatic) metabolic activity (Bernhard et al., 2006). Since metabolic activity stops after the death of the organism, CTG should give a much more accurate assessment of the living assemblages at the various sampling times and thereby avoid overestimation of the live foraminiferal abundances.

In this study, samples were collected in August and November 2011 and then every month through the year 2012, at two different stations in the Den Osse Basin, with two replicates dedicated to foraminifera. The two stations were chosen in contrasted environments regarding water depth (34 and $23 \mathrm{~m}$, respectively) and duration of seasonal hypoxia-anoxia and sulfidic conditions. Living foraminiferal assemblages were studied in the uppermost sediment and size distributions were determined in order to get insight into the possible moment(s) of reproduction or accelerated growth in test size. The seasonal variability study of the foraminiferal community allows us (1) to better understand the foraminiferal tolerance of seasonal hypoxia-anoxia with the presence of free $\mathrm{H}_{2} \mathrm{~S}$ in their microhabitat and (2) to obtain information about the responses of the various species to adverse conditions. This knowledge will be useful for the development of indices assessing environmental quality (i.e. biomonitoring) and may also improve palaeoecological interpretations of coastal records (e.g. Murray, 1967; Gustafsson and Nordberg, 1999).

\section{Material and methods}

\subsection{Studied area - environmental settings in the Den Osse Basin}

Lake Grevelingen is a part of the former Rhine-MeuseScheldt estuary, in the southwestern Netherlands. This former estuarine branch was turned into an artificial saltwater lake during the Delta Works project. In Lake Grevelingen, the water circulation is strongly limited by the construction of dams (in the early 1970s) and only a small sluice allows water exchanges with open seawater (i.e. very weak hydrodynamics). In the lake, development of bottom-water hypoxiaanoxia occurs in the deepest part of the basin in summer (i.e. July-September) to early autumn (i.e. October-December; Bannink et al., 1984; Hagens et al., 2015). In the literature, the terminology and threshold values used to describe oxygen depletion are highly variable (e.g. oxic, dysoxic, hypoxic, suboxic, microxic, postoxic; see Jorissen et al., 2007; Altenbach et al., 2012). In this study we defined hypoxia as a concentration of oxygen $<63 \mu \mathrm{mol} \mathrm{L}^{-1}\left(1.4 \mathrm{~mL} \mathrm{~L}^{-1}\right.$ or $2 \mathrm{mg} \mathrm{L}^{-1}$ ) whereas anoxia is defined as no detectable oxygen (following Rabalais et al., 2010).

In Den Osse Basin, the nutrient input from external sources is very low and pelagic-benthic coupling is essential, as already noted by de Vries and Hopstaken (1984). In 2012, phytoplankton blooms occurred in April-May and July (Hagens et al., 2015) in response to the increasing solar radiation and nutrient availability in the water column following organic matter recycling in winter. This led to an increased food availability in the benthic compartment in the same periods. In general, Chl $a$ concentrations in Den Osse Basin are below $10 \mu \mathrm{g} \mathrm{L} \mathrm{L}^{-1}$, excluding very short peaks during blooms in April-May and July which did not exceed $30 \mu \mathrm{g} \mathrm{L}^{-1}$ in 2012 (Hagens et al., 2015). Thermal stratification of the water column and increased oxygen consumption due to organic matter input (i.e. from phytoplankton blooms) are both responsible for the development of seasonal bottom-water hypoxiaanoxia in summer (i.e. July-September). Although euxinia (i.e. the presence of free $\mathrm{H}_{2} \mathrm{~S}$ in the water column) does not occur in the Den Osse Basin due to cable bacterial activity in winter, free $\mathrm{H}_{2} \mathrm{~S}$ is present in the uppermost layer of the 
sediment in summer (Seitaj et al., 2015). Summarising, in the benthic ecosystem, increased food availability in summer is counterbalanced by strongly decreasing oxygen contents, sometimes accompanied by the presence of free sulfides in the topmost sediment.

\subsection{Field sampling}

The two studied sites are located along a depth gradient in the Den Osse Basin of Lake Grevelingen. Both station 1 $\left(51^{\circ} 44.834^{\prime} \mathrm{N}, 3^{\circ} 53.401^{\prime} \mathrm{E}\right)$ and station $2\left(51^{\circ} 44.956^{\prime} \mathrm{N}\right.$, $\left.3^{\circ} 53.826^{\prime} \mathrm{E}\right)$ are located in the main channel, at 34 and $23 \mathrm{~m}$ depth, respectively (Fig. 1).

Measurements of bottom-water oxygen (BWO) concentrations were performed at $2 \mathrm{~m}$ above the sediment-water interface and are from Donders et al. (2012), whereas the data for 2012 were published in Hagens et al. (2015). Sediment cores were collected monthly in 2012 using a single core gravity corer (UWITEC, Austria) using PVC core liners $(6 \mathrm{~cm}$ inner diameter, $60 \mathrm{~cm}$ length). All cores were inspected upon retrieval and only visually undisturbed sediment cores were used for further analysis (Seitaj et al., 2017). Oxygen penetration depth (OPD) and depth of free $\mathrm{H}_{2} \mathrm{~S}$ detection were determined by Seitaj et al. (2015) using profiling microsensors for station 1. The data for station 2 (Supplement Table S1) were acquired similarly and during the same cruises but never published; for further details about the sampling method, see Seitaj et al. (2015).

Two replicate sediment cores dedicated to the foraminiferal study were sampled in August and November 2011 using the same gravity corer (UWITEC, Austria) and then monthly throughout the year 2012 at the same sampling time as for BWO concentration and OPD and $\mathrm{H}_{2} \mathrm{~S}$ measurements in the sediment (see Seitaj et al., 2015). Consequently, for 2012 at stations 1 and 2, OPD and $\mathrm{H}_{2} \mathrm{~S}$ were measured in the sediment column at the same time as foraminifera were sampled (Seitaj et al., 2015). For each replicate, the uppermost centimetre $(0-1 \mathrm{~cm})$ of the core was then transferred on board in a vial of $250 \mathrm{~mL}$, and $30 \mathrm{~mL}$ of seawater (at the same temperature as in situ) was added to the vial. Then we labelled the samples with CellTracker ${ }^{\mathrm{TM}}$ Green CMFDA (CTG, 5-chloromethylfluorescein diacetate, final concentration of $1 \mu \mathrm{mol} \mathrm{L}{ }^{-1}$ following Bernhard et al., 2006) and slowly agitated manually to allow the CTG diffusion in the whole sample. Samples were then fixed in $5 \%$ sodium-borate-buffered formalin after $24 \mathrm{~h}$ of incubation in the dark.

\subsection{Sample treatment}

All samples were sieved over 315,150 and $125 \mu \mathrm{m}$ meshes, and foraminiferal assemblages were studied in all three size fractions. Individuals were picked wet under an epifluorescence stereomicroscope (Olympus SZX12, light fluorescent source Olympus URFL-T, excitation/emission wavelengths:
Table 1. Sampling dates of the samples which were investigated for living foraminifera for stations 1 and 2 . $\mathrm{X}$ : one core investigated; $\mathrm{O}$ : no core investigated.

\begin{tabular}{llrcc}
\hline Year & Month & Day & Station 1 & Station 2 \\
\hline 2011 & Aug & 22 & X X & X X \\
2011 & Nov & 15 & X X & X X \\
2012 & Jan & 23 & X X & X X \\
2012 & Mar & 12 & X X & X X \\
2012 & May & 30 & X X & X X \\
2012 & Jul & 24 & X X & X X \\
2012 & Sep & 20 & X X & X X \\
2012 & Oct & 18 & O & X X \\
2012 & Nov & 2 & X X & X X \\
2012 & Dec & 3 & O & X X \\
\hline
\end{tabular}

$492 \mathrm{~nm} / 517 \mathrm{~nm}$ ) and placed on micropalaeontological slides. Only specimens that fluoresced brightly green were considered living and were identified to the (morpho)species level when possible. Since picking foraminifera under an epifluorescence stereomicroscope is particularly time-consuming, we decided to study samples only every 2 months for the year 2012. At a later stage, in view of the large differences in foraminiferal abundances between the samples of September and November 2012 at station 2, we decided to study the October and December 2012 samples as well for this station. The sampling dates investigated in this study are listed in Table 1 .

Abundances were then standardised to a volume of $10 \mathrm{~cm}^{3}$. The abundances of living foraminifera for each sampling time and replicate are listed in Tables S2 and S3. The mean abundance and standard deviation $(\bar{x} \pm \mathrm{SD})$ for the two replicates for each sampling date were calculated for both the total living assemblage and the individual species, as an indication of spatial patchiness.

\subsection{Taxonomy of dominant species}

Four dominant species ( $>1 \%$ of the total assemblage) were present in our material: Ammonia sp. T6, Elphidium magellanicum (Heron-Allen and Earland, 1932), Elphidium selseyense (Heron-Allen and Earland, 1911) and Trochammina inflata (Montagu, 1808). As we identified these species on the basis of morphological criteria, we will use them as "morphospecies".

Concerning the genus Ammonia, two living specimens collected at Grevelingen station 1 were molecularly identified (by DNA barcoding) as phylotype T6 by Bird et al. (2019). At the same site, we genotyped seven other living Ammonia specimens, which were all T6. Their sequences were deposited in GenBank (accession numbers MN190684 to MN190690), and Supplement Fig. S1 shows scanning electron microscope (SEM) images of the spiral side and of the penultimate chamber at $1000 \times$ magnification for four indi- 


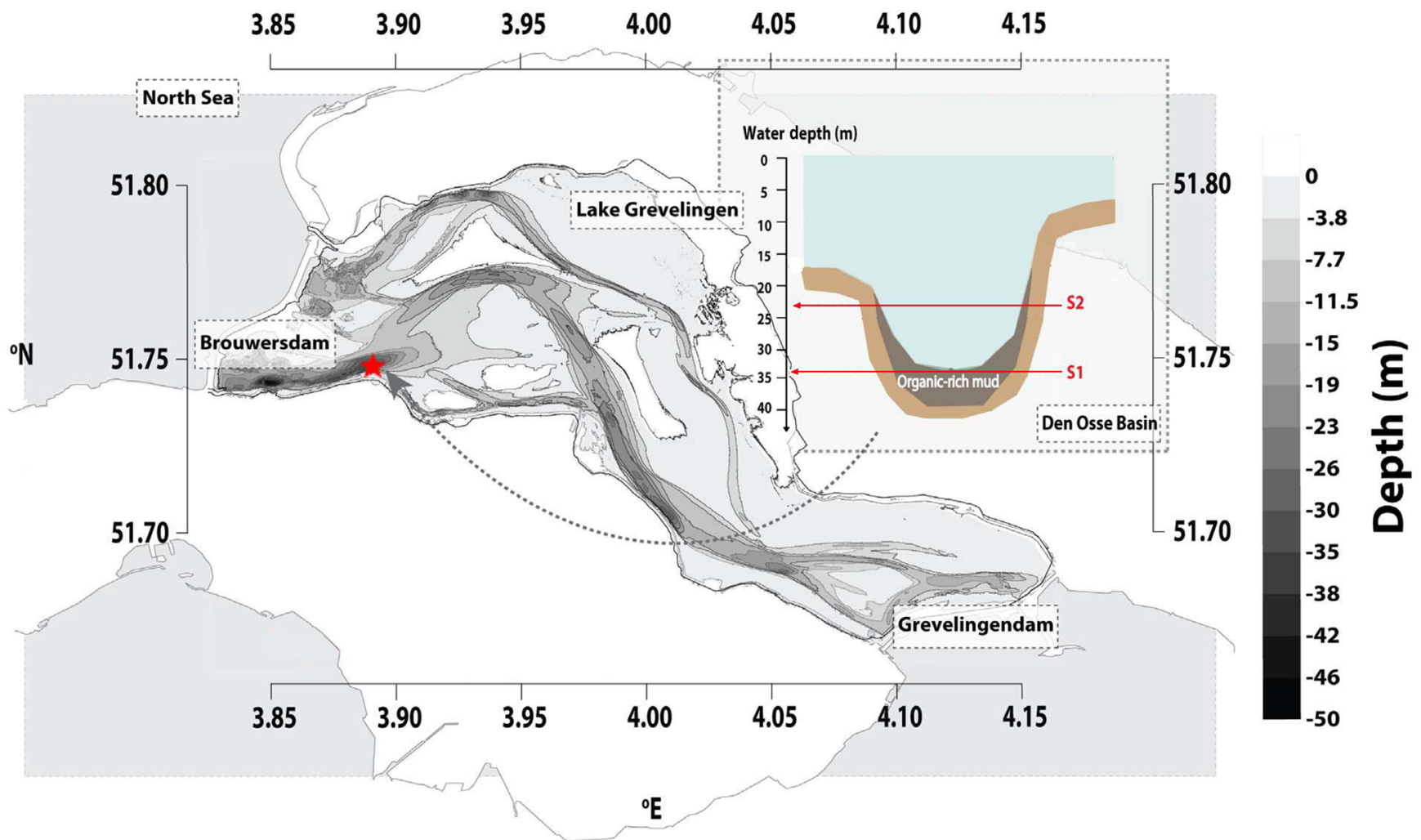

Figure 1. Map of Lake Grevelingen showing the location of the two sampled stations in the Den Osse Basin (red star). The transversal section of the Den Osse Basin (top right) shows the depth at which station 1 (S1) and station 2 (S2) were sampled (34 and $23 \mathrm{~m}$ depth, respectively). This figure was modified from Sulu-Gambari et al. (2016b).

viduals. A morphological screening based on the criteria proposed by Richirt et al. (2019) confirmed that T6 accounts for the vast majority (>98\%) of Ammonia individuals, whereas phylotypes T1, T2, T3 and T15 are only present in very small amounts (Table S3).

The specimens of Elphidium magellanicum were identified exclusively on the basis of morphological criteria, as there are no molecular data available yet. This morphospecies, although rare, is regularly recognised in Boreal and Lusitanian provinces of Europe (e.g. Gustafsson and Nordberg, 1999; Darling et al., 2016; Alve et al., 2016). However, as the type species was described from the Strait of Magellan (Southern Chile), the European specimens may represent a different species and further studies involving DNA sequencing of both populations are needed to confirm or disprove this taxonomic attribution (see Roberts et al., 2016).

Elphidium selseyense has often been considered an ecophenotype of Elphidium excavatum (Terquem, 1875) and has been identified as E. excavatum forma selseyensis (e.g. Feyling-Hanssen, 1972; Miller et al., 1982). Four living specimens were already sampled for DNA analysis at station 1 and were all identified as the species E. selseyense (phylotype S5, Darling et al., 2016). We only observed minor morphological variations in our material, especially concerning the number of small bosses in the umbilical region, which we considered to be intraspecific variability. Consequently, we identified all our specimens as E. selseyense.

The specimens attributed to Trochammina inflata were also identified exclusively on the basis of morphological criteria, as no molecular data are available yet.

\subsection{Size distribution measurement}

In order to detect periods of increased growth and/or reproduction, size measurements were performed on all samples of 2012. The measurements were made for all species (4176 individuals for station 1 and 19624 individuals for station 2), and trochospiral species were all orientated spiral side up prior to measurements. High-resolution images (3648 pixels $\times 2736$ pixels) of all micropalaeontological slides were taken with a stereomicroscope (Leica S9i, 10× magnification) and individual measurements were processed using ImageJ software (Schneider et al., 2012, Fig. S2).

Each individual was isolated (Fig. S2) and its maximum diameter was measured (i.e. Feret's diameter). We represented all size distributions using histograms with $20 \mu \mathrm{m}$ classes (the best compromise between the total number of individuals and the size range (Fig. S3). As we only examined the size fractions $>125 \mu \mathrm{m}$, our analysis mainly concerns 
adult specimens and does not include juveniles. This limitation should be kept in mind when interpreting the results.

Assuming that the size distribution was a sum of Gaussian curves, each of them representing a cohort, we tried to identify the approximate mode for the Gaussian curves (i.e. cohorts) using the changes in slope (i.e. inflexion points) of the second-order derivative of the total size distribution (Gammon et al., 2017). Unfortunately, this tentative attempt to distinguish cohorts by using a deconvolution method was not conclusive. The main problem was the lack of information concerning individuals smaller than $125 \mu \mathrm{m}$, so that our size distributions were systematically skewed toward small individuals. Because the identification of individual cohorts was not successful, a study of population dynamics was not possible. For this reason, the data are only shown in Figs. S2 and S3. Nevertheless, the size distribution data give some clues concerning the possible moment(s) of reproduction or intensified test growth for the different species.

\subsection{Encrusted forms of $E$. magellanicum}

In our samples, we found abundant encrusted forms of $E$. magellanicum at station 1 (May 2012) and station 2 (May, July, September and December 2012, Fig. 2). Most individuals were totally encrusted (Fig. 2a), others only partly (Fig. 2b). These crusts were hard, firmly stuck to the shell (difficult to remove with a brush), thin (Fig. 2c-e) and rather coarse. In order to determine if the crust matrix is constituted of carbonate, we placed some specimens in microtubes and exposed them to $0.1 \mathrm{M}$ of EDTA (ethylenediaminetetraacetic acid) diluted in $0.1 \mathrm{M}$ cacodylate buffer (acting as a carbonate chelator). After an exposition of $24 \mathrm{~h}$, we checked under a stereomicroscope if the crust was still cohesive (no carbonate in the crust) or was disaggregated (crust contains carbonate).

\section{Results}

\subsection{Total abundances of foraminiferal assemblages}

Averaged total abundances varied between $1.1 \pm 1.5$ and $449.9 \pm 322.1$ ind. $10 \mathrm{~cm}^{-3}$ for station 1 and between $91.1 \pm$ 25.0 and $604.8 \pm 3.5$ ind $10 \mathrm{~cm}^{-3}$ for station 2 (Fig. 3 and Table 2). For every studied month, the total density was higher at station 2 than at station 1 . The seasonal succession is very different between the two sites (Fig. 3). Station 1 shows very low total foraminiferal abundances for most months, contrasting with much higher densities in May and July. Conversely, station 2 shows high total foraminiferal abundances throughout the year, with somewhat lower values in November 2011 and October and November 2012 (Fig. 3).

At station 1, almost no individuals were present in August $(\bar{x}=3.4 \pm 1.3)$ and November $2011(\bar{x}=1.1 \pm 1.5)$. In 2012, total abundances were very low in January $(\bar{x}=11.5 \pm 9.3)$, showed a slight increase in March $(\bar{x}=62.1 \pm 19.3)$ and reached a maximal abundance in May $(\bar{x}=449.9 \pm 322.1)$.
Total abundances then progressively decreased from May to September $(\bar{x}=34.0 \pm 17.0)$ and almost no foraminifera were present in November $(\bar{x}=1.6 \pm 0.3)$.

At station 2, total abundances were comparatively low in August and November $2011(\bar{x}=174.0 \pm 48.0$ and $\bar{x}=$ $128.7 \pm 25$. ind. $10 \mathrm{~cm}^{-3}$, respectively). In 2012, total abundances were relatively high and stable from January to September (between $\bar{x}=523.6 \pm 30.7$ and $\bar{x}=604.8 \pm 3.5$ ), then decreased in October $(\bar{x}=211.5 \pm 8.0)$ and November $(\bar{x}=91.1 \pm 25.3)$, and finally increased again in December $(\bar{x}=377.9 \pm 38.8)$.

\subsection{Dominant species}

At station 1, the major species were, in order of decreasing abundances, Elphidium selseyense (Fig. 4a-b), Elphidium magellanicum (Fig. 4c-d) and Ammonia sp. T6 (Fig. 4eg). In Fig. 4, we added Trochammina inflata (Fig. 4h-j) to facilitate comparison with station 2 , where this species is among the dominant ones. The "other species" account only for $2.2 \%$ of the total assemblage at station 1 . The fact that they are well represented in some months (e.g. $26.3 \%$ of the assemblage in August 2011) is due to the extremely low number of individuals (see Fig. 3 and Table 2). At station 2, the dominant species, in order of decreasing abundances, were E. selseyense, Ammonia sp. T6, E. magellanicum and T. inflata (Table 2). Here, "other species" account only for $2.6 \%$ of the total assemblage. Whereas E. selseyense and $E$. magellanicum were dominant species at both stations, both Ammonia sp. T6 and T. inflata were present in much higher abundances at station 2 compared to station 1, where the latter species was almost absent (Figs. 5-6).

At station 1, only some very scarce individuals of $E$. selseyense were observed in August and November 2011 (Fig. 5 and Table 2). In 2012, E. selseyense abundances were very low in January and started to increase in March $(\bar{x}=$ $23.9 \pm 6.8)$, reaching maximal values in May $(\bar{x}=336.5 \pm$ 275.8). In July, values for $E$. selseyense were still high $(\bar{x}=$ $162.0 \pm 121.5$ ) and further decreased until an almost total absence in November 2012. No specimen of E. magellanicum was observed in 2011 (Fig. 5 and Table 2). The abundance of E. magellanicum was very low in January 2012, started to increase in March $(\bar{x}=21.6 \pm 11.0)$, reaching maximal values in May $(\bar{x}=96.4 \pm 47.3)$, and then strongly decreased in July $(\bar{x}=3.7 \pm 0.3)$. The species was absent from samples in September and November 2012. Ammonia sp. T6 was almost absent in August and November 2011 and present with very few specimens in January $2012(\bar{x}=3.2 \pm 3.5)$. Maximum abundances were reached between March and July 2012 (ranging between $\bar{x}=9.2 \pm 6.5$ and $\bar{x}=12.9 \pm 1.3$ ). Then abundances rapidly decreased until the species was almost absent in November. Trochammina inflata was absent in 2011 and was only present in very low abundances from January to May and in September 2012. 

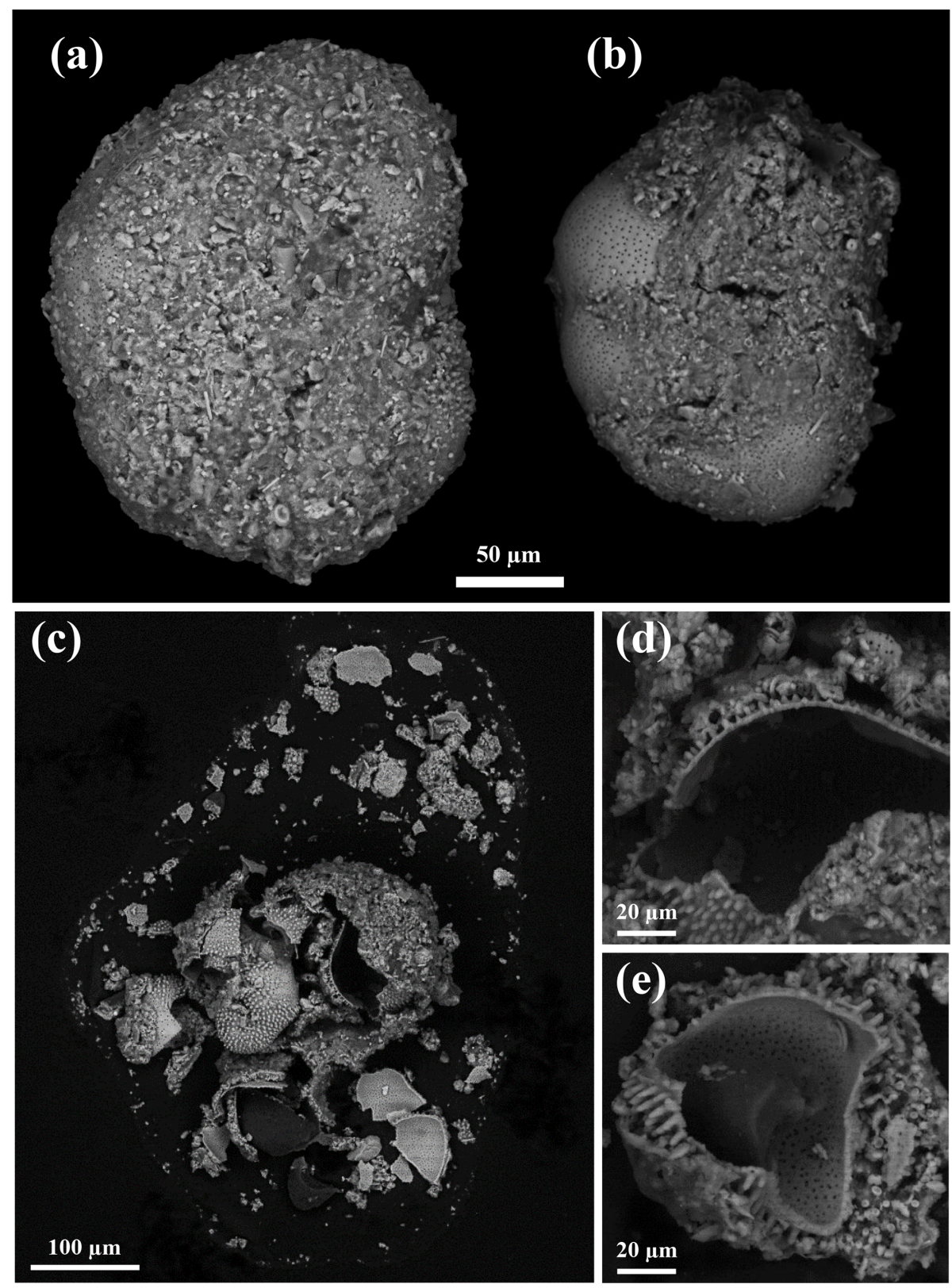

Figure 2. SEM images of fully encrusted specimen (a), partially encrusted specimen (b) and crushed encrusted specimen of Elphidium magellanicum (c). Note the thinness of the crust and the spinose structures in (d) and (e).

At station 2, the two dominant species were E. selseyense and Ammonia sp. T6, which together always represented at least $70 \%$ of the total assemblage (Fig. 6 and Table 2). These two species showed a different seasonal pattern over the considered period. Abundances of E. selseyense were comparable in August $(\bar{x}=74.8 \pm 29.8)$ and November 2011 $(\bar{x}=52.3 \pm 27.0)$ and then showed a progressive increase until a maximum in September $2012(\bar{x}=365.5 \pm 70.3)$. Abundances then showed a sharp decrease in October and November (respectively $\bar{x}=98.7 \pm 8.5$ and $\bar{x}=30.9 \pm 2.3$ ) to increase again in December $(\bar{x}=252.2 \pm 41.0)$. For Ammo- nia sp. T6, abundances strongly increased between November $2011(\bar{x}=60.8 \pm 1.5)$ and January $2012(\bar{x}=226.2 \pm$ 52.3) and then progressively decreased until the end of 2012 $(\bar{x}=48.1 \pm 26.0$ in November 2012). Trochammina inflata showed an analogous pattern to Ammonia sp. T6. Abundances strongly increased between November $2011(\bar{x}=$ $11.8 \pm 1.8)$ and January $2012(\bar{x}=121.5 \pm 29.8)$ and then progressively decreased until very low abundances in November $(\bar{x}=3.7 \pm 3.0)$. E. magellanicum was completely absent in August and November 2011, almost absent in January 2012 $(\bar{x}=0.9 \pm 0.3)$, and then suddenly increased until a max- 


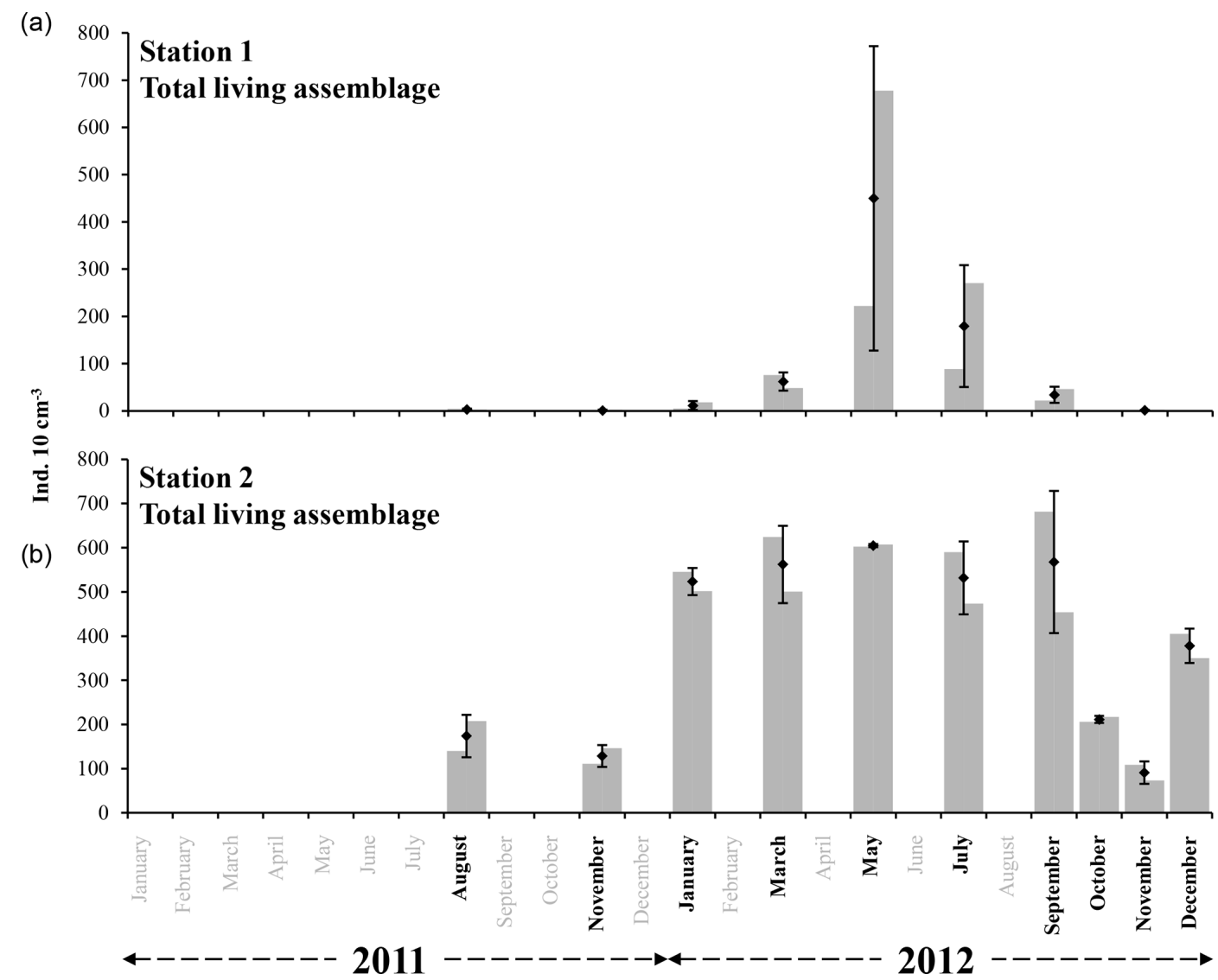

Figure 3. The grey bars represent the living foraminiferal abundances for the two replicates. The mean abundances (diamonds) and standard deviations (black error bars) were calculated for the two replicates for stations 1 ( $34 \mathrm{~m} \mathrm{depth,} \mathrm{a)} \mathrm{and} 2$ ( $23 \mathrm{~m}$ depth, b). All abundance values are for the $0-1 \mathrm{~cm}$ layer and were standardised to $10 \mathrm{~cm}^{3}$. Months where foraminiferal communities were investigated are indicated in bold (excluding October and December at station 1).

imum of $\bar{x}=116.0 \pm 6.5$ in May. Abundances stayed relatively high in July $(\bar{x}=37.8 \pm 2.5)$ and September $(\bar{x}=$ $72.0 \pm 35.8)$ and then drastically decreased until minimum numbers in October and November. Finally, like all other species, E. magellanicum abundances increased again in December $(\bar{x}=25.5 \pm 13.0)$.

\subsection{Encrusted forms of Elphidium magellanicum}

After exposition to $0.1 \mathrm{M}$ of EDTA diluted in $0.1 \mathrm{M}$ cacodylate buffer, the crusts remained cohesive, indicating that they do not consist of carbonate and suggesting that they are composed of sediment particles cemented by an organic matrix.

At station 1, encrusted forms of E. magellanicum were present in moderate proportions in May (26.8\% of the total E. magellanicum population, Fig. 7) and July (47.6\%); the species disappeared thereafter. At station 2, encrusted forms strongly dominated the E. magellanicum population from May (72.3\%) to December (88.0\%, Fig. 7).

\section{Discussion}

\subsection{Tolerance of foraminiferal communities towards anoxia and free sulfide}

At station 1, bottom waters were hypoxic in July 2012 and became anoxic in August (Fig. 8). Both in July and in August, oxygen penetration into the sediment was null, whereas it was $0.7 \pm 0.1 \mathrm{~mm}$ depth in September. In all 3 months (July to September 2012), sulfidic conditions were observed very close to the sediment-water interface $(1 \mathrm{~mm}$ or less, Fig. 8 and Table S1). In view of these results, the duration of anoxic and sulfidic conditions in the uppermost sediment layer can be estimated as 1 to 2 months (in July and August, Fig. 8).

After the strong increase in foraminiferal densities in May 2012, there was a decrease starting in July, leading to a near absence of foraminifera at station 1 in November (Fig. 8). The most probable cause of the strong decline of the foraminiferal community appears to be a prolonged presence of sulfides in the foraminiferal microhabitat. However, the fact that foraminiferal abundances reached almost 
Table 2. Mean living foraminiferal absolute (ind. $10 \mathrm{~cm}^{-3}$ ) and relative abundances (percentage of the total fauna, in parentheses) of the dominant species. Last column: absolute abundance of the total fauna.

\begin{tabular}{|c|c|c|c|c|c|c|c|}
\hline Year & Month & Elphidium selseyense & Ammonia sp. T6 & Elphidium magellanicum & Trochammina inflata & Others & Total \\
\hline \multicolumn{8}{|c|}{ Station 1} \\
\hline 2011 & Aug & $1.2(36.8)$ & $1.2(36.8)$ & $0.0(0.0)$ & $0.0(0.0)$ & $0.9(26.3)$ & 3.4 \\
\hline 2011 & Nov & $0.5(50.0)$ & $0.4(33.3)$ & $0.0(0.0)$ & $0.0(0.0)$ & $0.2(16.7)$ & 1.1 \\
\hline 2012 & Jan & $5.1(44.6)$ & $3.2(27.7)$ & $0.2(1.5)$ & $1.2(10.8)$ & $1.8(15.4)$ & 11.5 \\
\hline 2012 & Mar & $23.9(38.5)$ & $12.9(20.8)$ & $21.6(34.8)$ & $1.4(2.3)$ & $2.3(3.7)$ & 62.1 \\
\hline 2012 & May & $336.5(74.8)$ & $9.2(2.0)$ & $96.4(21.4)$ & $1.8(0.4)$ & $6.0(1.3)$ & 449.9 \\
\hline 2012 & Jul & $162.0(90.2)$ & $10.3(5.7)$ & $3.7(2.1)$ & $0.0(0.0)$ & $3.5(2.0)$ & 179.5 \\
\hline 2012 & Sep & $29.7(87.5)$ & $2.3(6.8)$ & $0.0(0.0)$ & $0.4(1.0)$ & $1.6(4.7)$ & 34.0 \\
\hline 2012 & Nov & $1.1(66.7)$ & $0.4(22.2)$ & $0.0(0.0)$ & $0.0(0.0)$ & $0.2(11.1)$ & 1.6 \\
\hline Sum & & $560.0(75.4)$ & $39.8(5.4)$ & $121.8(16.4)$ & $4.8(0.6)$ & $16.4(2.2)$ & 742.9 \\
\hline \multicolumn{8}{|c|}{ Station 2} \\
\hline 2011 & Aug & $74.8(43.0)$ & $82.1(47.2)$ & $0.0(0.0)$ & $14.7(8.4)$ & $2.5(1.4)$ & 174.0 \\
\hline 2011 & Nov & $52.3(40.7)$ & $60.8(47.3)$ & $0.0(0.0)$ & $11.8(9.2)$ & 3.7 (2.9) & 128.7 \\
\hline 2012 & Jan & $161.8(30.9)$ & $226.2(43.2)$ & $0.9(0.2)$ & $121.5(23.2)$ & $13.3(2.5)$ & 523.6 \\
\hline 2012 & Mar & $214.7(38.2)$ & $214.0(38.1)$ & $48.8(8.7)$ & $75.0(13.3)$ & $9.9(1.8)$ & 562.3 \\
\hline 2012 & May & $288.2(47.7)$ & $147.1(24.3)$ & $116.0(19.2)$ & $36.1(6.0)$ & $17.3(2.9)$ & 604.8 \\
\hline 2012 & Jul & $282.6(53.2)$ & $158.4(29.8)$ & $37.8(7.1)$ & $31.5(5.9)$ & $21.2(4.0)$ & 531.6 \\
\hline 2012 & Sep & 365.5 (64.4) & $102.4(18.0)$ & $72.0(12.7)$ & $16.1(2.8)$ & $11.5(2.0)$ & 567.5 \\
\hline 2012 & Oct & $98.7(46.7)$ & $99.0(46.8)$ & $1.8(0.8)$ & $7.4(3.5)$ & $4.6(2.2)$ & 211.5 \\
\hline 2012 & Nov & $30.9(34.0)$ & $48.1(52.8)$ & $4.1(4.5)$ & $3.7(4.1)$ & $4.2(4.7)$ & 91.1 \\
\hline 2012 & Dec & $252.2(66.7)$ & $78.0(20.6)$ & $25.5(6.7)$ & $12.7(3.4)$ & $9.5(2.5)$ & 377.9 \\
\hline Sum & & $1821.8(48.3)$ & $1216.1(32.2)$ & $306.8(8.1)$ & $330.5(8.8)$ & 97.7 (2.6) & 3773.0 \\
\hline
\end{tabular}

zero only in September (about 2 months after the first occurrence of anoxic and sulfidic conditions in the upper sediment, in July) suggests that the presence of $\mathrm{H}_{2} \mathrm{~S}$ did not cause instantaneous mortality, but that the disappearance of the foraminiferal community was a delayed response, probably caused by inhibited reproduction and, eventually, increased mortality. Inhibited reproduction has previously been suggested as a response to hypoxic-short anoxic (Geslin et al., 2014) and sulfidic conditions (Moodley et al., 1998b).

Such a time lag between a change in foraminiferal abundances and changes in environmental parameters affecting reproduction and/or growth of foraminifera has been suggested previously by Duijnstee et al. (2004). These authors highlighted that the density patterns of some foraminiferal species showed a higher correlation with measured environmental parameters (e.g. oxygenation or temperature) when a time lag of about 3 months was applied.

For 2011, at station 1, no pore-water $\mathrm{O}_{2}$ and $\mathrm{H}_{2} \mathrm{~S}$ measurements are available. However, severe hypoxia was observed in the bottom waters from May to August, with anoxia in June 2011 (Fig. 8). We therefore assume that, like in 2012, anoxic and probably co-occurring sulfidic conditions were responsible for the very low standing stocks in August and November 2011 and January 2012.
Our observations confirm the suggestion in previous studies that the foraminiferal community is severely affected by a long-term presence of $\mathrm{H}_{2} \mathrm{~S}$ in its habitat but does not show instant mortality. In fact, after a $66 \mathrm{~d}$ incubation in euxinic conditions (a maximum of $11.9 \pm 0.4 \mu \mathrm{mol} \mathrm{L}^{-1}$ of $\mathrm{H}_{2} \mathrm{~S}$ in the overlying water) of foraminiferal assemblages collected at a $19 \mathrm{~m}$ deep site in the Adriatic Sea, Moodley et al. (1998a) found a strong decrease in the total density of Rose Bengalstained foraminifera. After $21 \mathrm{~d}$, living specimens were still observed, whereas after 42 and $66 \mathrm{~d}$, the live checks (based on protoplasm movement) gave only negative results. Langlet et al. $(2013,2014)$ performed an in situ experiment with closed benthic chambers at a $24 \mathrm{~m}$ deep site in the Gulf of Trieste, in the Adriatic Sea. They observed a decrease in living foraminiferal density (labelled with CTG), but they also found that almost all species survived after 10 months of anoxia and periodically co-occurring $\mathrm{H}_{2} \mathrm{~S}$ in the sediment and overlying water. However, the duration of sulfidic conditions, which was estimated to be several weeks, could not be assessed precisely (Metzger et al., 2014). The suggestion that short exposure to euxinic conditions is not directly lethal for foraminifera is confirmed by the experimental results of Bernhard (1993), who found that foraminiferal activity (as determined by ATP content) was not significantly affected after $30 \mathrm{~d}$ exposure to euxinia $(32.6 \pm 8.6 \%$ of active indi- 


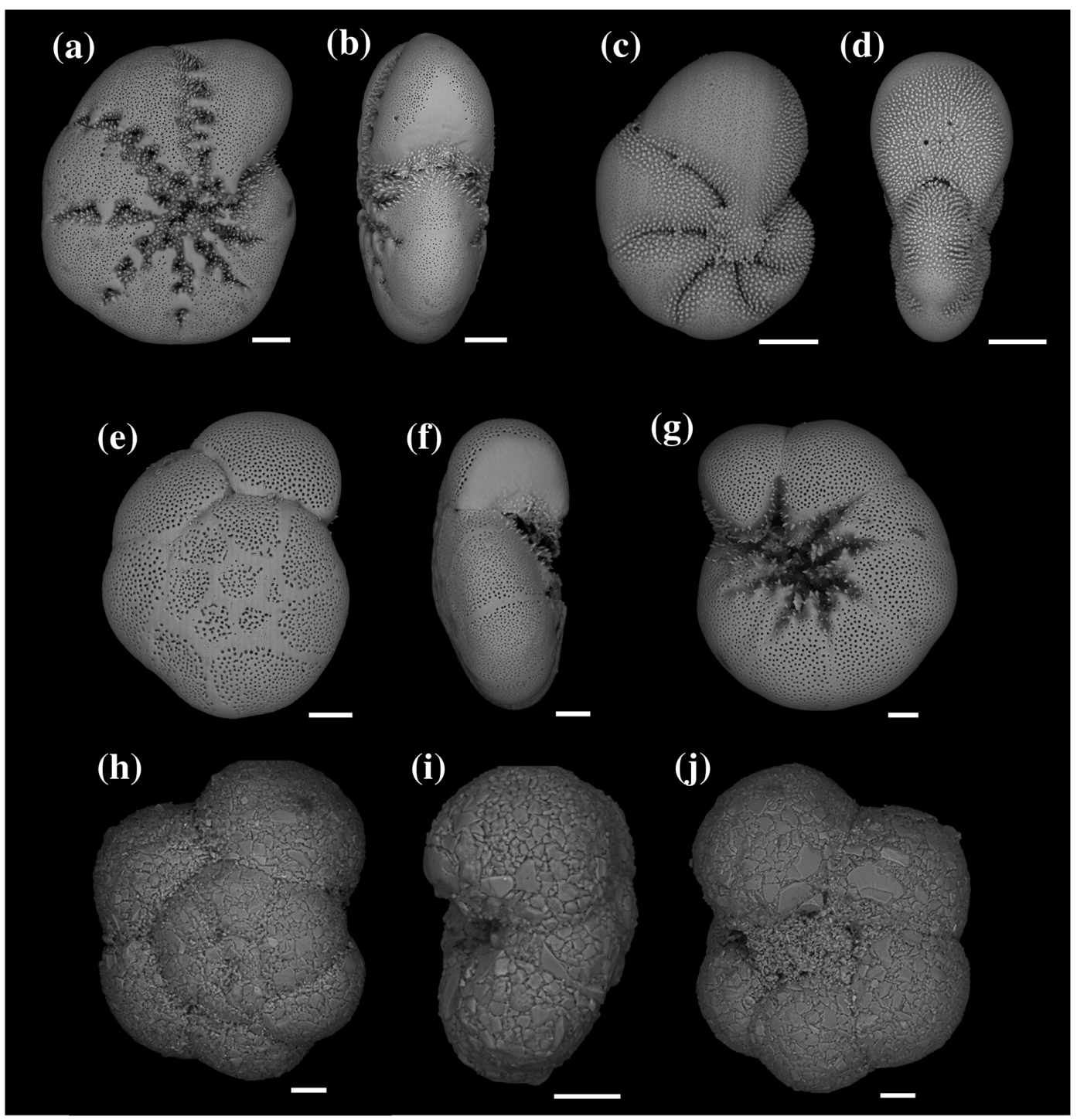

Figure 4. SEM images of Elphidium selseyense in lateral (a) and peripheral (b) views; Elphidium magellanicum in lateral (c) and peripheral (d) views; Ammonia sp. T6 in spiral (e), peripheral (f) and umbilical (g) views; and Trochammina inflata in spiral (h), peripheral (i) and umbilical (j) views. All scale bars are $50 \mu \mathrm{m}$.

viduals, $n=174$ in control conditions versus $29.5 \pm 6.2 \%$, $n=173$ in sulfidic conditions).

After the 2011 hypoxia-anoxia, standing stocks at station 1 only started to increase in March 2012, indicating a very long recovery time (about 6 months) of the foraminiferal faunas after a temporary near-extinction due to anoxic and sulfidic conditions. This confirms observations of relatively long recovery times in the literature (e.g. Alve, 1995, 1999; Gustafsson and Nordberg, 2000; Hess et al., 2005). For instance, Gustafsson and Nordberg (1999) showed that in the Koljö Fjord, at comparable water depths, foraminiferal populations responded with increased densities only 3 months after a renewal of sea-floor oxygenation following hypoxic conditions in the bottom waters. However, in that case, the disappearance of the foraminiferal population was only partial and not nearly as complete as in our study.

At station 2, in 2012, hypoxia was only observed in August, when the OPD was zero, and sulfidic conditions were observed in the superficial sediment (i.e. from $0.4 \pm 0.2 \mathrm{~mm}$ downwards, Fig. 9, Table S1). Both in July and in September, oxygen penetrated more than $1 \mathrm{~mm}$ into the sediment $(1.3 \pm 0.4$ and $1.2 \pm 0.2 \mathrm{~mm}$, respectively). However, free $\mathrm{H}_{2} \mathrm{~S}$ was still detected at about $1 \mathrm{~mm}$ depth in the sediment $(1.1 \pm 0.8 \mathrm{~mm}$ in July and $0.8 \pm 0.2 \mathrm{~mm}$ in September). Although the sampling plan does not allow us to be very precise about the duration of anoxic and sulfidic conditions, we can estimate their duration to be 1 month or less (Fig. 9). 


\section{Station 1}

(a)

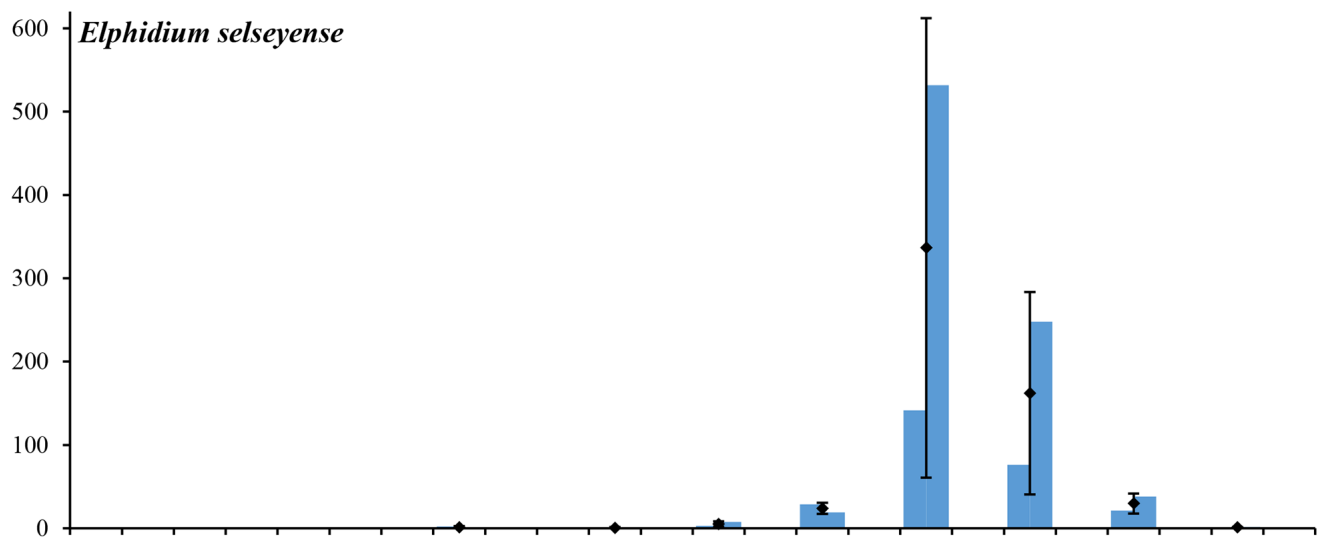

(b)

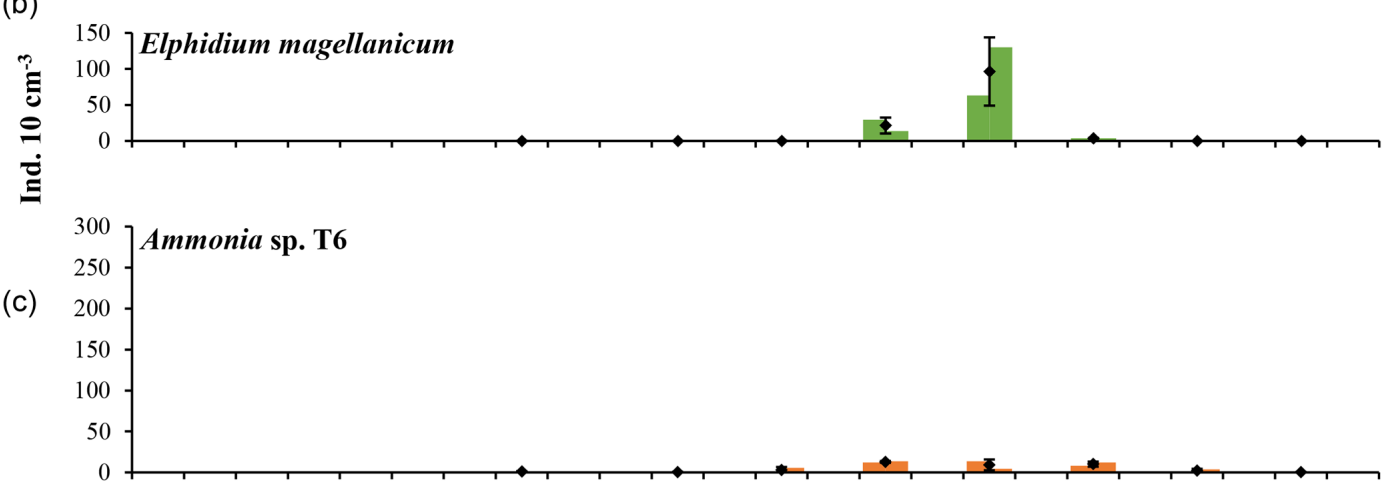

(d) $150-$ Trochammina inflata

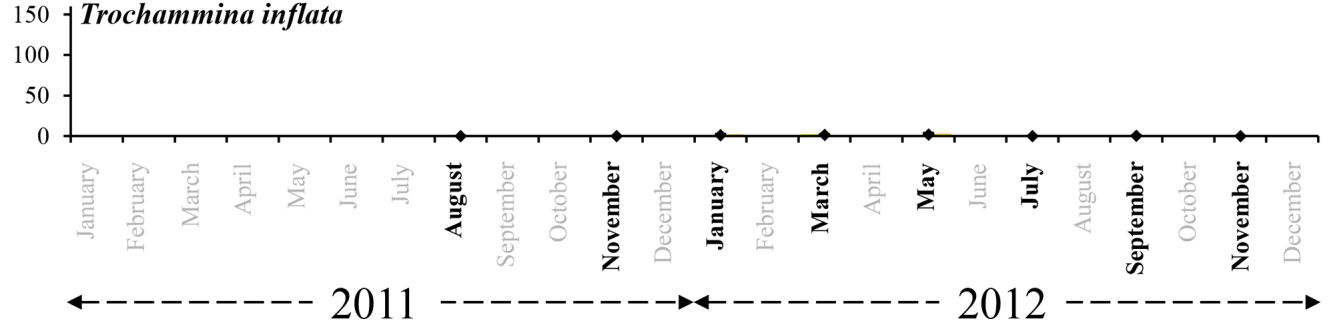

Figure 5. The bars represent the living foraminiferal abundances for the two replicates for Elphidium selseyense (a), Elphidium magellanicum (b), Ammonia sp. T6 (c) and Trochammina inflata (d) at station 1 in 2011 and 2012. The mean abundances (diamonds) and standard deviations (black error bars) were calculated for the two replicates. All abundance values are for the $0-1 \mathrm{~cm}$ layer and were standardised to $10 \mathrm{~cm}^{3}$. Months when foraminiferal communities were investigated are indicated in bold. Scales were chosen in order to facilitate comparison with station 2 .

Foraminiferal abundances showed a strong decrease in October and November 2012, about 2 months after the presence of anoxic and sulfidic conditions in the topmost part of the sediment (Fig. 9). Like at station 1, this temporal offset between the presence of anoxia-sulfidic conditions at station 2 (in August) and the strong decrease in faunal densities may be explained as a delayed response, mainly due to inhibited reproduction during the anoxic-sulfidic event. If true, the mortality of adults did not strongly increase in the months following the $\mathrm{H}_{2} \mathrm{~S}$ production in the uppermost sediment.
Nevertheless, there was no replacement in the $>125 \mu \mathrm{m}$ fraction by growing juveniles, probably because reproduction was interrupted when $\mathrm{H}_{2} \mathrm{~S}$ was present in the foraminiferal microhabitat. A renewed recruitment after the last stage of sulfidic conditions somewhere in September would then explain why the faunal density in the $>125 \mu \mathrm{m}$ fraction increased again in December 2012 (Fig. S3).

In 2011, at station 2, bottom waters oscillated between hypoxic and oxic conditions between May and August (Fig. 9). Although we have no measurements of $\mathrm{H}_{2} \mathrm{~S}$ in the pore 


\section{Station 2}

(a)

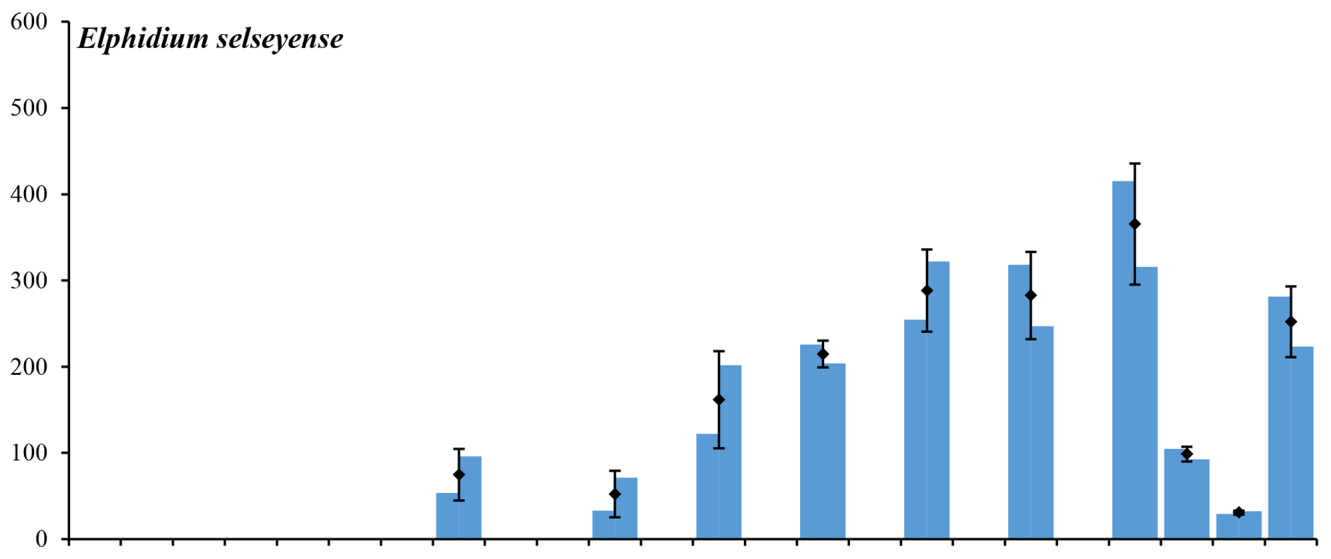

(b)
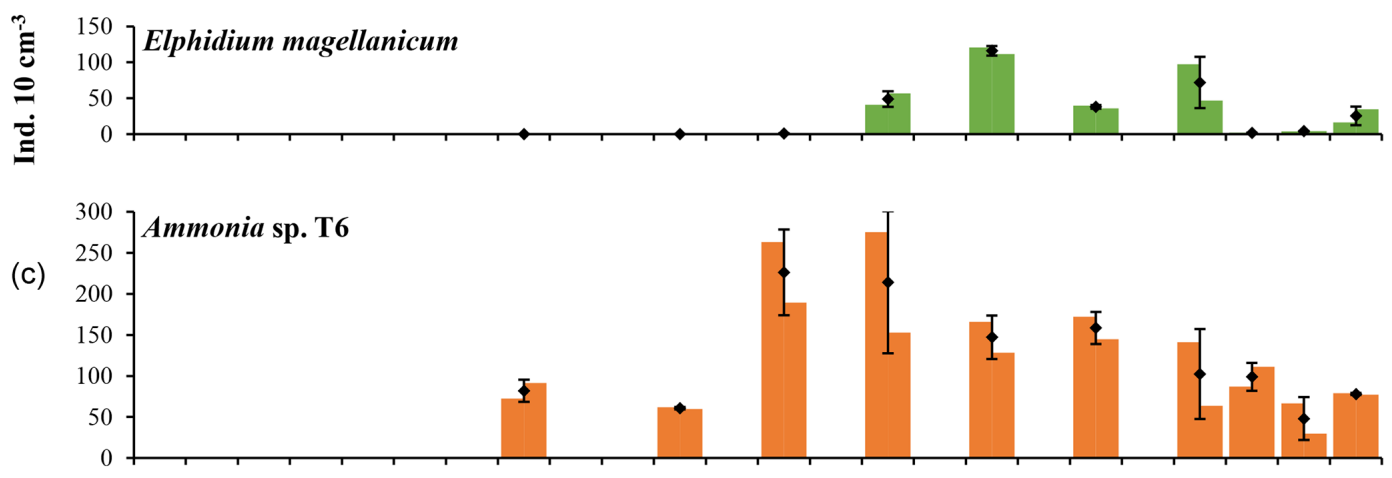

(d)

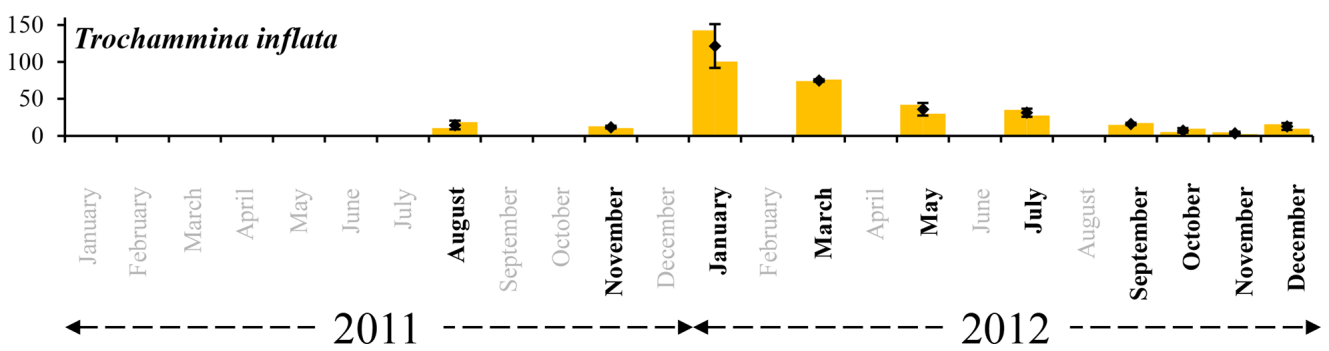

Figure 6. The bars represent the living foraminiferal abundances for the two replicates for Elphidium selseyense (a), Elphidium magellanicum (b), Ammonia sp. T6 (c) and Trochammina inflata (d) at station 2 in 2011 and 2012. The mean abundances (diamonds) and standard deviations (black error bars) were calculated for the two replicates. All abundances values are for the $0-1 \mathrm{~cm}$ layer and were standardised to $10 \mathrm{~cm}^{3}$. Months when foraminiferal communities were investigated are indicated in bold. Scales were chosen in order to facilitate comparison with station 1 .

waters for this year, it seems probable that bottom-water hypoxia was accompanied by the presence of free $\mathrm{H}_{2} \mathrm{~S}$ very close to the sediment surface, strongly affecting the foraminiferal communities. If we assume that, like in 2012, rich foraminiferal fauna was present in May-July 2011 at both stations, the low faunal densities observed in August and November 2011 could suggest that foraminifera may have also shown a delayed response to sulfidic conditions in 2011.
It is interesting to note that the foraminiferal densities observed at station 2 were lower in August 2011 than in July or September 2012. This may be a consequence of the repetition of short hypoxic events in the bottom water between May and August 2011 (probably associated with anoxia and maybe $\mathrm{H}_{2} \mathrm{~S}$ in the uppermost part of the sediment), which possibly affected the foraminiferal community more substantially in 2011 than in 2012, when a hypoxic event was recorded in August only. 
(a)

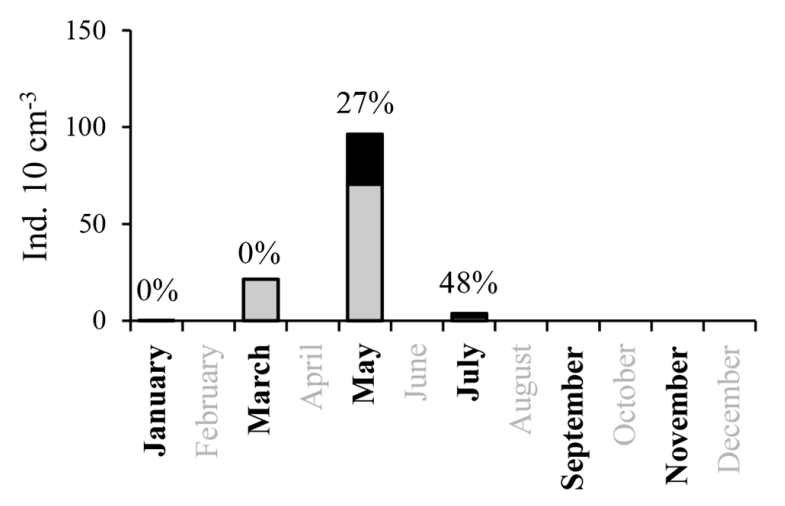

(b)

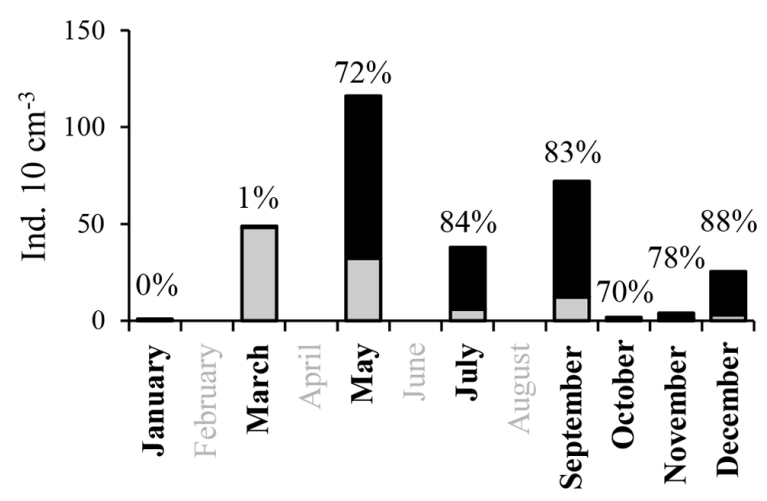

\section{Elphidium magellanicum $\square$ Encrusted form}

Figure 7. Mean abundances (ind. $10 \mathrm{~cm}^{-3}$ ) of non-encrusted (grey) and encrusted forms (black) of Elphidium magellanicum in 2012 , at stations 1 (a) and 2 (b), with proportion of encrusted forms above each bar (\%). Investigated months are indicated in bold.

The important decrease in total standing stocks at station 2 in October and November 2012 (Fig. 9) suggests that, in spite of the shorter duration of anoxia and sulfide conditions (compared to station 1; 1 month or less compared to 1 to 2 months), the foraminiferal faunas were still strongly affected. However, at station 2, foraminiferal abundances increased again in December 2012, suggesting a recovery time of about 2 months, which is likely much shorter than at station 1 , where standing stocks in the $>125 \mu \mathrm{m}$ fraction only increased 6 months after the presence of anoxia and free sulfides.

Summarising, the foraminiferal communities of both stations 1 and 2 seem strongly impacted by the anoxic and sulfidic conditions developing in the uppermost part of the sediment in summer (i.e. July-September). However, at station 1, where anoxic and sulfidic conditions lasted for 1 to 2 months, the response is much stronger, leading ultimately (in November) to almost complete disappearance of the foraminiferal fauna. The delayed response at both stations shows that instantaneous mortality was limited and suggests that the decreasing standing stocks might rather be the result of inhibited reproduction and, eventually, increased mortality. Recovery is much faster at station 2 (about 2 months) than at station 1 (about 6 months), probably because at station 1 (in contrast to station 2) the foraminiferal extinction was nearly complete, and the site had to be recolonised (e.g. possibly by nearby sites or by the remaining few individuals) after reoxygenation of the sediment. At station 2, a reduced but significant foraminiferal community remained present, explaining the faster recovery.

\subsection{Species-specific response to anoxia, sulfide and food availability in Lake Grevelingen}

The comparison of the different seasonal patterns of the major species at the two investigated stations allows us to draw some conclusions about interspecific differences in the response to seasonal anoxic and sulfidic conditions.

First, there is a clear faunal difference between the two stations. Station 1 is dominated by E. selseyense and E. magellanicum while at station 2 these two taxa are accompanied by Ammonia sp. T6 and T. inflata. The latter species is almost absent at station 1, where Ammonia sp. T6 is present with low densities. At first glance, the dominance of the two Elphidium species at station 1 would suggest that they have a greater tolerance of the seasonal anoxic and sulfidic conditions, which lasted much longer there. It is interesting to note that the temporal evolution of standing stocks at station 1 is different for the two Elphidium species. Elphidium magellanicum shows a strong drop in absolute density in July 2012, at the onset of $\mathrm{H}_{2} \mathrm{~S}$ presence in the uppermost part of the sediment, whereas the diminution of E. selseyense is more progressive and the species disappears almost completely only in November (Fig. 5). This strongly suggests that E. magellanicum is more affected by increased mortality than $E$. selseyense in response to the combined effects of anoxic and sulfidic conditions. This hypothesis is confirmed by the patterns observed at station 2, where the drop in standing stocks in October-November is also more drastic in E. magellanicum than in E. selseyense (Fig. 6).

As mentioned earlier, certain species of foraminifera can use an anaerobic metabolism (i.e. denitrification; RisgaardPetersen et al., 2006; Piña-Ochoa et al., 2010a), sequester chloroplasts (i.e. kleptoplastidy; Jauffrais et al., 2018), host bacterial symbionts (Bernhard et al., 2010) or enter dor- 


\section{Station 1}

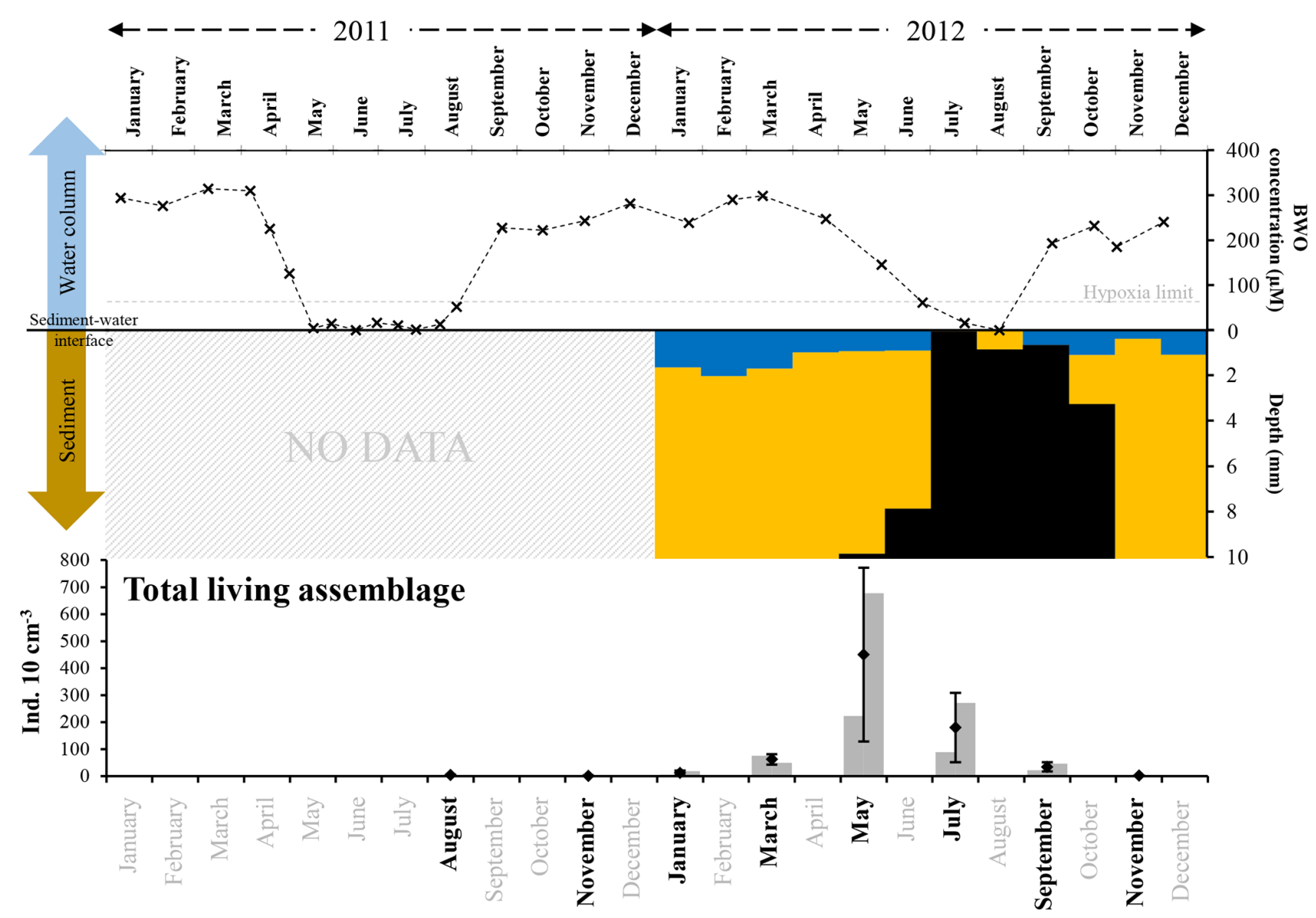

Figure 8. The top panel represents bottom-water oxygen concentrations $(\mu \mathrm{mol} \mathrm{L}-1)$ in 2011 and 2012 at station 1, from Donders et al. (2012) and Seitaj et al. (2017). The grey horizontal dotted line indicates the hypoxia limit $\left(63 \mu \mathrm{mol} \mathrm{L} \mathrm{L}^{-1}\right)$. The middle panel represents the depth $(\mathrm{mm})$ distribution of the oxic zone (blue), absence of oxygen and sulfides (orange), and sulfidic zone (black) within the sediment in 2012, from Seitaj et al. (2015). The bottom panel shows the total living foraminiferal abundances for both replicates (grey bars), mean abundances (diamonds) and standard deviations (black error bars) calculated for the two replicates, for all investigated months (in bold) in 2011 and 2012.

mancy (Ross and Hallock, 2016; LeKieffre et al., 2017) to deal with low-oxygen conditions. Concerning the species found in this study, although the presence of intracellular nitrate was shown for Ammonia, denitrification tests yielded negative results (Piña-Ochoa et al., 2010a; Nomaki et al., 2014). Similarly, the presence of active symbionts was previously suggested for Ammonia but never confirmed (Nomaki et al., 2016; Bernhard et al., 2018). To our knowledge, denitrification or the presence of bacterial symbionts was never shown for Elphidium either. In conclusion, a shift to an alternative anaerobic metabolism or an association with bacterial symbionts has never been shown conclusively for the dominant foraminiferal species found in Lake Grevelingen.

The greater tolerance of E. selseyense towards low-oxygen conditions could be explained by the fact that it is able to sequester chloroplasts from ingested diatoms and keep them active for several days to weeks, in contrast to Ammonia sp. T6 (Jauffrais et al., 2018). These active chloroplasts could serve as an alternative source of oxygen and/or food through photosynthesis (Bernhard and Alve, 1996) or another metabolic pathway (Jauffrais et al., 2019) and thereby increase the capability of this species to survive anoxic events. Although sequestration of chloroplasts was never investigated for E. magellanicum, its abundant spinose ornamentation in the umbilical region and in the vicinity of the aperture (Fig. 4c-d) suggests that this species is capable of crushing diatom frustules like some kleptoplastic species (Bernhard and Bowser, 1999; Austin et al., 2005). Hagens et al. (2015) observed that the light penetration depth in the Den Osse Basin never exceeded $15 \mathrm{~m}$ in 2012, and therefore photosynthesis by kleptoplasts (Bernhard and Alve, 1996) appears unlikely for both our aphotic stations (34 and $23 \mathrm{~m}$ 


\section{Station 2}

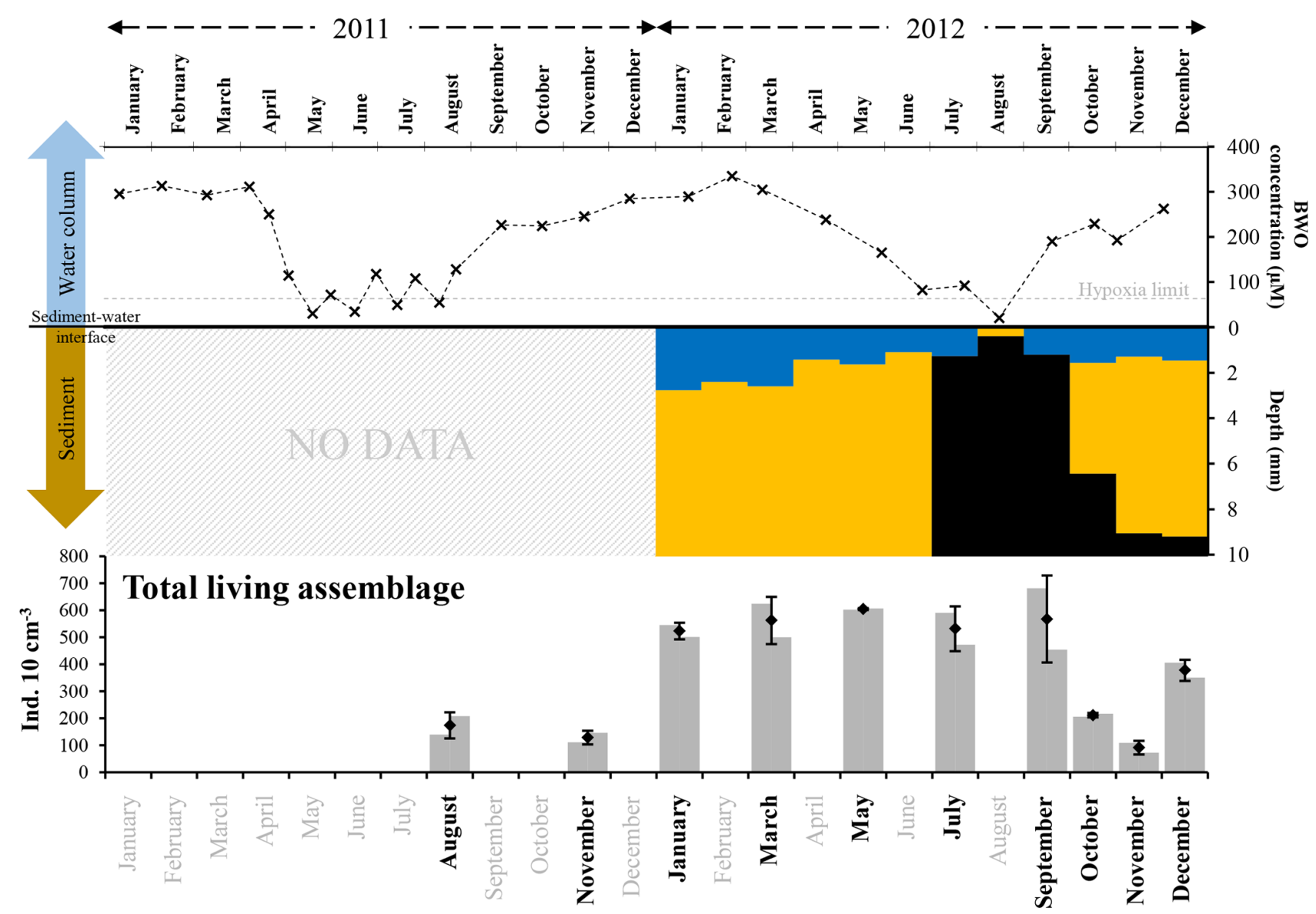

Figure 9. The top panel represents bottom-water oxygen concentrations $\left(\mu \mathrm{mol} \mathrm{L}{ }^{-1}\right)$ in 2011 and 2012 at station 2, from Donders et al. (2012) and Seitaj et al. (2017). The grey horizontal dotted line indicates the hypoxia limit $\left(63 \mu \mathrm{mol} \mathrm{L} \mathrm{L}^{-1}\right)$. The middle panel represents the depth $(\mathrm{mm})$ distribution of the oxic (blue), suboxic (orange, absence of oxygen and sulfides) and sulfidic (black) zones within the sediment in 2012. The bottom panel shows the total living foraminiferal abundances for both replicates (grey bars), mean abundances (diamonds) and standard deviations (black error bars) calculated for the two replicates, for all investigated months (in bold) in 2011 and 2012.

depth). However, other foraminifera from aphotic and anoxic environments such as deep fjords are kleptoplastic and use these kleptoplasts for a yet unknown purpose (Jauffrais et al., 2019).

Rather surprisingly, the drop in foraminiferal densities at station 2 in October-November, which we interpreted as a delayed response to sulfidic conditions, is less strong for $\mathrm{Am}$ monia sp. T6 than for the two Elphidium species, suggesting that this species is less affected. However, this does not agree with our previous suggestion that the two Elphidium species would be more tolerant to anoxic and sulfidic conditions. As already proposed by LeKieffre et al. (2017), Ammonia seems to be able to deal with anoxia (up to $28 \mathrm{~d}$, but with no sulfide) by reducing its metabolic activity, but this ability was never shown for Elphidium species. If E. selseyense and E. magellanicum are indeed unable to resist anoxia by reducing their metabolism or by entering a dormancy state, this could ex- plain their stronger decrease in density at station 2 compared to Ammonia sp. T6. Nevertheless, further studies about the ability and mechanisms of the two Elphidium species to resist anoxic-sulfidic conditions are necessary.

Another remarkable observation is that Ammonia sp. T6 (and T. inflata) shows maximum densities in January-March, contrasting with the two Elphidium species, which have their density maxima later in the year (May-September). This temporal offset could possibly be explained by a difference in preferential food source, with food particles available in winter (January-March) being more suitable for Ammonia sp. T6 (and T. inflata) and food particles available later in the year, resulting from phytoplankton blooms, being more favourable for E. selseyense and E. magellanicum.

In our study, for E. selseyense (and E. magellanicum), the continuous presence of a high proportion of small-sized specimens and progressively increasing densities between 
January and September 2012 strongly suggest ongoing and continuous reproduction (Fig. S3a). Continuous reproduction during the year has been described earlier for different foraminiferal genera, such as Elphidium, Ammonia, Haynesina, Nonion and Trochammina (e.g. Jones and Ross, 1979; Murray, 1983, 1992; Cearreta, 1988; Basson and Murray, 1995; Gustafsson and Nordberg, 1999; Murray and Alve, 2000). Conversely, for Ammonia sp. T6, a decrease in densities coupled with a rapid increase in overall test size between March and May 2012 (small sized specimens remain present but in smaller proportions) could be indicative of a period of reduced recruitment (Fig. S3b).

In fact, foraminifera exhibit a large range of feeding strategies, with several species showing selective feeding with specific food particles (Muller, 1975; Suhr et al., 2003; Chronopoulou et al., 2019). Hagens et al. (2015) reported that in Lake Grevelingen the phytoplankton composition was different between April-May and July 2012. In April-May, the phytoplankton bloom was mainly composed of the haptophyte Phaeocystis globose (Scherffel, 1899), whereas it was dominated by the dinoflagellate Prorocentrum micans (Ehrenberg, 1834) in July. Elphidium was reported to be able to feed on various food sources (e.g. diatoms, dinoflagellates, green algae; Correia and Lee, 2002; Pillet et al., 2011). However, diatoms are a major food source for kleptoplastic species (Bernhard and Bowser, 1999), such as E. selseyense (Jauffrais et al., 2018; Chronopoulou et al., 2019). Ammonia spp. seem able to feed on very diverse food sources including microalgae, diatoms, bacteria or even metazoans (Lee et al., 1969; Moodley et al., 2000; Dupuy et al., 2010; Jauffrais et al., 2016; Chronopoulou et al., 2019). Recently, Chronopoulou et al. (2019) showed different feeding preferences for Ammonia sp. T6 and E. selseyense in intertidal environments in the Dutch Wadden Sea. Although diatoms are ingested by both species (but much more by E. selseyense), dinoflagellates were consumed by $E$. selseyense but not by Ammonia sp. T6. The latter species is also capable of feeding on metazoans by active predation (Dupuy et al., 2010).

These observations suggest that at station 2 the different seasonal density patterns of Ammonia sp. T6 and the two Elphidium species are not the consequence of a large difference in tolerance of anoxia-sulfides, but rather a different adjustment to the seasonal cycle of food availability. At station 1, the very low densities of Ammonia sp. T6 could possibly be explained by a recolonisation starting in January, when food conditions were favourable for this taxon (as testified by the strong density increase in January 2012 at station 2). However, once a more abundant pioneer population had developed (in March-May), food conditions may have been no longer favourable for Ammonia sp. T6, explaining why its density did not show a further increase. Conversely, the food conditions may have become optimal for the two Elphidium species, explaining their strong density increase between March and May 2012. If true, this would mean that the lower densities of Ammonia sp. T6 would not be due to a lower resistance to anoxia and free sulfides, but rather due to an unfavourable seasonal succession of food availability. Previous studies already suggested that hypoxic-anoxic conditions coupled with increased food input from autumnal phytoplankton blooms (composed of diatoms and dinoflagellates) would favour the development of E. magellanicum (Gustafsson and Nordberg, 1999). The fact that also at station 2 this species was mainly observed between March and September 2012 corroborates our conclusion of its dependence on a specific food regime.

Finally, encrusted forms of E. magellanicum were observed at both stations from May until the end of the year but were absent in the samples of March 2012. In view of the fact that the crusts consist mainly of organic matter, the encrusted individuals appear to be specimens with preserved feeding cysts. The precise functions of cysts observed around foraminifera are not clear and include feeding, reproduction, chamber formation, protection or resting (Cedhagen, 1996; Heinz et al., 2005). Concerning the cysts of E. magellanicum described here, very similar observations have been made for Elphidium incertum at different locations (Norwegian Greenland Sea and Baltic Sea in Linke and Lutze, 1993; Koljö Fjord in Gustafsson and Nordberg, 1999; Kiel Bight in Polovodova et al., 2009). If we assume that encrusted specimens indeed present the remains of feeding cysts, the observation of abundant encrusted specimens corroborates our conclusion that the surface water phytoplankton bloom in May 2012 (i.e. probably mainly Phaeocystis globosa) provided a food source particularly well suited to the nutritional preferences of this species.

\section{Conclusions}

In this study we examined the foraminiferal community response to different durations of seasonal anoxia coupled with the presence of sulfide in the uppermost layer of sediment at two stations in Lake Grevelingen. In both stations investigated, foraminiferal communities are highly impacted by the combination of anoxia and $\mathrm{H}_{2} \mathrm{~S}$ in their habitat. The foraminiferal response varied depending on the duration of adverse conditions and led to a near extinction at station 1 , where anoxic and sulfidic conditions were present for 1 to 2 months, compared to a drop in standing stocks at station 2, where these conditions lasted for 1 month or less. At both sites, foraminiferal communities showed a 2-month delay in the response to anoxic and sulfidic conditions, suggesting that the presence of $\mathrm{H}_{2} \mathrm{~S}$ inhibited reproduction, whereas mortality was not necessarily increased. The duration of the subsequent recovery depended on whether the foraminiferal community was almost extinct (station 1) or remained present with reduced numbers (station 2). In the former case, 6 months were needed for faunal recovery, whereas in the latter case, it took only 2 months. We hypothesise that the dominance of E. selseyense and E. magellanicum at sta- 
tion 1 is not due to a lower tolerance of Ammonia sp. T6 towards anoxic and sulfidic conditions, but is rather the consequence of a different adjustment between the two Elphidium species and Ammonia sp. T6 with respect to the seasonal cycle of food availability.

Data availability. Raw data are available in the Supplement.

Supplement. The supplement related to this article is available online at: https://doi.org/10.5194/bg-17-1415-2020-supplement.

Author contributions. BR, DL and JR produced the foraminiferal data. DS, AM and CPS provided and interpreted geochemical data. MS provided, verified and integrated all available genetic information concerning the foraminiferal taxa of Lake Grevelingen. FJRM and CPS coordinated a much larger research project concerning Lake Grevelingen, of which this foraminiferal study is a part. They were also responsible for the foraminiferal sampling and provided environmental data. FJJ designed the foraminiferal study and directed the postdoctoral research of BR and, together with AM and MS, the PhD thesis of JR. All authors contributed actively to the several successive versions of the manuscript.

Competing interests. The authors declare that they have no conflict of interest.

Acknowledgements. We are very grateful to Sandra Langezaal for inviting us to study the fascinating environments of the Grevelingenmeer. We acknowledge the support of Pieter van Rijswijk, Mathilde Hagens, Anton Tramper and the crew of the R/V Luctor (Peter Coomans and Marcel Kristalijn) during the sampling campaigns. We are grateful to Romain Mallet and the team of the SCIAM imaging facility at the University of Angers. We acknowledge Jassin Petersen for his help with recovering some of the environmental data and Thierry Jauffrais and Charlotte LeKieffre for discussion about alternative metabolisms. This paper benefited from the comments and suggestions of Laurie M. Charrieau and the two anonymous reviewers.

Financial support. This research has been supported by Rijkswaterstaat and the CNRS programme CYBER-LEFE (project AMTEP).

Review statement. This paper was edited by Hiroshi Kitazato and reviewed by Laurie M. Charrieau and two anonymous referees.

\section{References}

Altenbach, A. V., Bernhard, J. M., and Seckbach, J. (Eds.): Anoxia: evidence for eukaryote survival and paleontological strategies, Springer, Dordrecht, 648 pp., 2012.

Alve, E.: Benthic foraminiferal distribution and recolonization of formerly anoxic environments in Drammensfjord, southern Norway, Mar. Micropaleontol., 25, 169-186, https://doi.org/10.1016/0377-8398(95)00007-N, 1995.

Alve, E.: Colonization of new habitats by benthic foraminifera: a review, Earth-Sci. Rev., 46, 167-185, https://doi.org/10.1016/S0012-8252(99)00016-1, 1999.

Alve, E. and Bernhard, J. M.: Vertical migratory response of benthic foraminifera to controlled oxygen concentrations in an experimental mesocosm, Mar. Ecol. Prog. Ser., 116, 137-151, ISSN 0171-8630, 1995.

Alve, E., Korsun, S., Schönfeld, J., Dijkstra, N., Golikova, E., Hess, S., Husum, K., and Panieri, G.: Foram-AMBI: A sensitivity index based on benthic foraminiferal faunas from North-East Atlantic and Arctic fjords, continental shelves and slopes, Mar. Micropaleontol., 122, 1-12, https://doi.org/10.1016/j.marmicro.2015.11.001, 2016.

Austin, H. A., Austin, W. E. N., and Paterson, D. M.: Extracellular cracking and content removal of the benthic diatom Pleurosigma angulatum (Quekett) by the benthic foraminifera Haynesina germanica (Ehrenberg), Mar. Micropaleontol., 57, 68-73, https://doi.org/10.1016/j.marmicro.2005.07.002, 2005.

Bannink, B. A., Van der Meulen, J. H. M., and Nienhuis, P. H.: Lake grevelingen: From an estuary to a saline lake. An introduction, Neth. J. Sea Res., 18, 179-190, https://doi.org/10.1016/00777579(84)90001-2, 1984.

Basson, P. W. and Murray, J. W.: Temporal Variations in Four Species of Intertidal Foraminifera, Bahrain, Arabian Gulf, Micropaleontology, 41, 69-76, https://doi.org/10.2307/1485882, 1995.

Bernhard, J. M.: Postmortem vital staining in benthic foraminifera; duration and importance in population and distributional studies, J. Foraminifer. Res., 18, 143-146, https://doi.org/10.2113/gsjfr.18.2.143, 1988.

Bernhard, J. M.: Experimental and field evidence of Antarctic foraminiferal tolerance to anoxia and hydrogen sulfide, Mar. Micropaleontol., 20, 203-213, https://doi.org/10.1016/03778398(93)90033-T, 1993.

Bernhard, J. M. and Alve, E.: Survival, ATP pool, and ultrastructural characterization of benthic foraminifera from Drammensfjord (Norway): response to anoxia, Mar. Micropaleontol., 28, 5-17, https://doi.org/10.1016/0377-8398(95)00036-4, 1996.

Bernhard, J. M. and Bowser, S. S.: Benthic foraminifera of dysoxic sediments: chloroplast sequestration and functional morphology, Earth-Sci. Rev., 46, 149-165, https://doi.org/10.1016/S00128252(99)00017-3, 1999.

Bernhard, J. M., Ostermann, D. R., Williams, D. S., and Blanks, J. K.: Comparison of two methods to identify live benthic foraminifera: A test between Rose Bengal and CellTracker Green with implications for stable isotope paleoreconstructions, Paleoceanography, 21, PA4210, https://doi.org/10.1029/2006PA001290, 2006.

Bernhard, J. M., Goldstein, S. T., and Bowser, S. S.: An ectobiont-bearing foraminiferan, Bolivina pacifica, that inhabits microxic pore waters: cell-biological and paleo- 
ceanographic insights, Environ. Microbiol., 12, 2107-2119, https://doi.org/10.1111/j.1462-2920.2009.02073.x, 2010.

Bernhard, J. M., Tsuchiya, M., and Nomaki, H.: U1trastructural observations on prokaryotic associates of benthic foraminifera: Food, mutualistic symbionts, or parasites?, Mar. Micropaleontol., 138, 33-45, https://doi.org/10.1016/j.marmicro.2017.09.001, 2018.

Bird, C., Schweizer, M., Roberts, A., Austin, W. E. N., Knudsen, K. L., Evans, K. M., Filipsson, H. L., Sayer, M. D. J., Geslin, E., and Darling, K. F.: The genetic diversity, morphology, biogeography, and taxonomic designations of Ammonia (Foraminifera) in the Northeast Atlantic, Mar. Micropaleontol., 155, 101726, https://doi.org/10.1016/j.marmicro.2019.02.001, 2019.

Bouchet, V. M. P., Debenay, J.-P., Sauriau, P.-G., RadfordKnoery, J., and Soletchnik, P.: Effects of short-term environmental disturbances on living benthic foraminifera during the Pacific oyster summer mortality in the MarennesOléron Bay (France), Mar. Environ. Res., 64, 358-383, https://doi.org/10.1016/j.marenvres.2007.02.007, 2007.

Cearreta, A.: Population dynamics of benthic foraminifera in the Santoña estuary, Spain, Revue de Paleobiologie, 2, 721-724, ISSN:0253-6730, 1988.

Cedhagen, T.: Foraminiferans as food for cephalaspideans (Gastropoda: Opisthobranchia), with notes on secondary tests around calcareous foraminiferans, Phuket Marine Biological Center Special Publication, 16, 279-290, 1996.

Chronopoulou, P.-M., Salonen, I., Bird, C., Reichart, G.-J., and Koho, K. A.: Metabarcoding Insights Into the Trophic Behavior and Identity of Intertidal Benthic Foraminifera, Front. Microbiol., 10, 1169, https://doi.org/10.3389/fmicb.2019.01169, 2019.

Cloern, J. E., Foster, S. Q., and Kleckner, A. E.: Phytoplankton primary production in the world's estuarine-coastal ecosystems, Biogeosciences, 11, 2477-2501, https://doi.org/10.5194/bg-112477-2014, 2014.

Corliss, B. H. and Emerson, S.: Distribution of rose bengal stained deep-sea benthic foraminifera from the Nova Scotian continental margin and Gulf of Maine, Deep-Sea Res. Pt. A, 37, 381-400, https://doi.org/10.1016/0198-0149(90)90015-N, 1990.

Correia, M. and Lee, J. J.: Fine structure of the plastids retained by the foraminifer Elphidium excavatum (Terquem), Symbiosis, 32, 15-26, ISSN: 03345114, 2002.

Darling, K. F., Schweizer, M., Knudsen, K. L., Evans, K. M., Bird, C., Roberts, A., Filipsson, H. L., Kim, J.-H., Gudmundsson, G., Wade, C. M., Sayer, M. D. J., and Austin, W. E. N.: The genetic diversity, phylogeography and morphology of Elphidiidae (Foraminifera) in the Northeast Atlantic, Mar. Micropaleontol., 129, 1-23, https://doi.org/10.1016/j.marmicro.2016.09.001, 2016.

de Vries, I. and Hopstaken, C. F.: Nutrient cycling and ecosystem behaviour in a salt-water lake, Neth. J. Sea Res., 18, 221-245, https://doi.org/10.1016/0077-7579(84)90003-6, 1984.

Diaz, R. J. and Rosenberg, R.: Marine benthic hypoxia: a review of its ecological effects and the behavioural responses of benthic macrofauna, Oceanogr. Mar. Biol., 33, 245-303, 1995.

Diaz, R. J. and Rosenberg, R.: Spreading Dead Zones and Consequences for Marine Ecosystems, Science, 321, 926-929, https://doi.org/10.1126/science.1156401, 2008.

Donders, T. H., Guasti, E., Bunnik, F. P. M., and van Aken, H.: Impact van de Brouwersdam op zuurstofcondities in de
Grevelingen; reconstructies uit natuurlijke sediment archieven, TNO-report TNO-060-UT-2011-02116, Utrecht, the Netherlands, 2012.

Dorman, D. C., Moulin, F. J.-M., McManus, B. E., Mahle, K. C., James, R. A., and Struve, M. F.: Cytochrome Oxidase Inhibition Induced by Acute Hydrogen Sulfide Inhalation: Correlation with Tissue Sulfide Concentrations in the Rat Brain, Liver, Lung, and Nasal Epithelium, Toxicol. Sci., 65, 18-25, https://doi.org/10.1093/toxsci/65.1.18, 2002.

Duijnstee, I., de Lugt, I., Vonk Noordegraaf, H., and van der Zwaan, B.: Temporal variability of foraminiferal densities in the northern Adriatic Sea, Mar. Micropaleontol., 50, 125-148, https://doi.org/10.1016/S0377-8398(03)00069-0, 2004.

Duijnstee, I. A. P., Ernst, S. R., and van der Zwaan, G. J.: Effect of anoxia on the vertical migration of benthic foraminifera, Mar. Ecol. Prog. Ser., 246, 85-94, https://doi.org/10.3354/meps246085, 2003.

Duijnstee, I. a. P., Nooijer, L. J. de, Ernst, S. R., and van der Zwaan, G. J.: Population dynamics of benthic shallow-water foraminifera: effects of a simulated marine snow event, Mar. Ecol. Prog. Ser., 285, 29-42, https://doi.org/10.3354/meps285029, 2005.

Dupuy, C., Rossignol, L., Geslin, E., and Pascal, P.-Y.: Predation of mudflat meio-macrofaunal metazoans by a calcareous foraminifer, Ammonia tepida (cushman, 1926), J. Foraminifer Res., 40, 305-312, https://doi.org/10.2113/gsjfr.40.4.305, 2010.

Ernst, S., Bours, R., Duijnstee, I., and van der Zwaan, B.: Experimental effects of an organic matter pulse and oxygen depletion on a benthic foraminiferal shelf community, J. Foraminifer. Res., 35, 177-197, https://doi.org/10.2113/35.3.177, 2005.

Feyling-Hanssen, R. W.: The Foraminifer Elphidium excavatum (Terquem) and Its Variant Forms, Micropaleontology, 18, 337354, https://doi.org/10.2307/1485012, 1972.

Gammon, P. R., Neville, L. A., Patterson, R. T., Savard, M. M., and Swindles, G. T.: A log-normal spectral analysis of inorganic grain-size distributions from a Canadian boreal lake core: Towards refining depositional process proxy data from high latitude lakes, Sedimentology, 64, 609-630, https://doi.org/10.1111/sed.12281, 2017.

Geslin, E., Heinz, P., Jorissen, F., and Hemleben, C.: Migratory responses of deep-sea benthic foraminifera to variable oxygen conditions: laboratory investigations, Mar. Micropaleontol., 53, 227-243, https://doi.org/10.1016/j.marmicro.2004.05.010, 2004

Geslin, E., Barras, C., Langlet, D., Nardelli, M. P., Kim, J.-H., Bonnin, J., Metzger, E., and Jorissen, F. J.: Survival, Reproduction and Calcification of Three Benthic Foraminiferal Species in Response to Experimentally Induced Hypoxia, in: Approaches to Study Living Foraminifera: Collection, Maintenance and Experimentation, edited by: Kitazato, H. and Bernhard, J. M., Springer Japan, Tokyo, 163-193, 2014.

Gilbert, D., Rabalais, N. N., Diaz, R. J., and Zhang, J.: Evidence for greater oxygen decline rates in the coastal ocean than in the open ocean, Biogeosciences, 2283-2296, https://doi.org/10.5194/bg7-2283-2010, 2010.

Gustafsson, M. and Nordberg, K.: Benthic foraminifera and their response to hydrography, periodic hypoxic conditions and primary production in the Koljö fjord on the Swedish west coast, J. Sea Res., 41, 163-178, https://doi.org/10.1016/S13851101(99)00002-7, 1999. 
Gustafsson, M. and Nordberg, K.: Living (Stained) Benthic Foraminifera and their Response to the Seasonal Hydrographic Cycle, Periodic Hypoxia and to Primary Production in Havstens Fjord on the Swedish West Coast, Estuar. Coast. Shelf Sci., 51, 743-761, https://doi.org/10.1006/ecss.2000.0695, 2000.

Hagens, M., Slomp, C. P., Meysman, F. J. R., Seitaj, D., Harlay, J., Borges, A. V., and Middelburg, J. J.: Biogeochemical processes and buffering capacity concurrently affect acidification in a seasonally hypoxic coastal marine basin, Biogeosciences, 12, 15611583, https://doi.org/10.5194/bg-12-1561-2015, 2015.

Hannah, F. and Rogerson, A.: The Temporal and Spatial Distribution of Foraminiferans in Marine Benthic Sediments of the Clyde Sea Area, Scotland, Estuar. Coast. Shelf Sci., 44, 377-383, https://doi.org/10.1006/ecss.1996.0136, 1997.

Heinz, P., Geslin, E., and Hemleben, C.: Laboratory observations of benthic foraminiferal cysts, Mar. Biol. Res., 1, 149-159, https://doi.org/10.1080/17451000510019114, 2005.

Hess, S., Jorissen, F. J., Venet, V., and Abu-Zied, R.: Benthic foraminiferal recovery after recent turbidite deposition in Cap Breton canyon, Bay of Biscay, J. Foraminifer. Res., 35, 114-129, https://doi.org/10.2113/35.2.114, 2005.

Jauffrais, T., Jesus, B., Geslin, E., Briand, F., and Jézéquel, V. M.: Locomotion speed of the benthic foraminifer Ammonia tepida exposed to different nitrogen and carbon sources, J. Sea Res., 118, 52-58, https://doi.org/10.1016/j.seares.2016.07.001, 2016.

Jauffrais, T., LeKieffre, C., Koho, K. A., Tsuchiya, M., Schweizer, M., Bernhard, J. M., Meibom, A., and Geslin, E.: Ultrastructure and distribution of kleptoplasts in benthic foraminifera from shallow-water (photic) habitats, Mar. Micropaleontol., 138, 4662, https://doi.org/10.1016/j.marmicro.2017.10.003, 2018.

Jauffrais, T., LeKieffre, C., Schweizer, M., Geslin, E., Metzger, E., Bernhard, J. M., Jesus, B., Filipsson, H. L., Maire, O., and Meibom, A.: Kleptoplastidic benthic foraminifera from aphotic habitats: insights into assimilation of inorganic $\mathrm{C}, \mathrm{N}$ and $\mathrm{S}$ studied with sub-cellular resolution, Environ. Microbiol., 21, 125-141, https://doi.org/10.1111/1462-2920.14433, 2019.

Jones, G. D. and Ross, C. A.: Seasonal Distribution of Foraminifera in Samish Bay, Washington, J. Paleontol., 53, 245-257, ISSN: 0022-3360, 1979.

Jørgensen, B. B., Postgate, J. R., Postgate, J. R., and Kelly, D. P.: Ecology of the bacteria of the sulphur cycle with special reference to anoxic - oxic interface environments, Philos. T. Roy. Soc. Lond. B, 298, 543-561, https://doi.org/10.1098/rstb.1982.0096, 1982.

Jorissen, F. J., Fontanier, C., and Thomas, E.: Chapter Seven Paleoceanographical Proxies Based on Deep-Sea Benthic Foraminiferal Assemblage Characteristics, in: Developments in Marine Geology, Vol. 1, edited by: Hillaire-Marcel, C. and De Vernal, A., Elsevier, 263-325, 2007.

Josefson, A. B. and Widbom, B.: Differential response of benthic macrofauna and meiofauna to hypoxia in the Gullmar Fjord basin, Mar. Biol., 100, 31-40, https://doi.org/10.1007/BF00392952, 1988.

Khan, A. A., Schuler, M. M., Prior, M. G., Yong, S., Coppock, R. W., Florence, L. Z., and Lillie, L. E.: Effects of hydrogen sulfide exposure on lung mitochondrial respiratory chain enzymes in rats, Toxicol. Appl. Pharmacol., 103, 482-490, https://doi.org/10.1016/0041-008X(90)90321-K, 1990.
Koho, K. A. and Piña-Ochoa, E.: Benthic Foraminifera: Inhabitants of Low-Oxygen Environments, in: Anoxia: Evidence for Eukaryote Survival and Paleontological Strategies, edited by: Altenbach, A. V., Bernhard, J. M., and Seckbach, J., Springer Netherlands, Dordrecht, 249-285, 2012.

Koho, K. A., Piña-Ochoa, E., Geslin, E., and Risgaard-Petersen, N.: Vertical migration, nitrate uptake and denitrification: survival mechanisms of foraminifers (Globobulimina turgida) under low oxygen conditions, FEMS Microbiol. Ecol., 75, 273-283, https://doi.org/10.1111/j.1574-6941.2010.01010.x, 2011.

Langlet, D., Geslin, E., Baal, C., Metzger, E., Lejzerowicz, F., Riedel, B., Zuschin, M., Pawlowski, J., Stachowitsch, M., and Jorissen, F. J.: Foraminiferal survival after long-term in situ experimentally induced anoxia, Biogeosciences, 10, 7463-7480, https://doi.org/10.5194/bg-10-7463-2013, 2013.

Langlet, D., Baal, C., Geslin, E., Metzger, E., Zuschin, M., Riedel, B., Risgaard-Petersen, N., Stachowitsch, M., and Jorissen, F. J.: Foraminiferal species responses to in situ, experimentally induced anoxia in the Adriatic Sea, Biogeosciences, 11, 17751797, https://doi.org/10.5194/bg-11-1775-2014, 2014.

Lee, J. J., Muller, W. A., Stone, R. J., McEnery, M. E., and Zucker, W.: Standing crop of foraminifera in sublittoral epiphytic communities of a Long Island salt marsh, Mar. Biol., 4, 44-61, https://doi.org/10.1007/BF00372165, 1969.

LeKieffre, C., Spangenberg, J., Mabilleau, G., Escrig, S., Meibom, A., and Geslin, E.: Surviving anoxia in marine sediments: The metabolic response of ubiquitous benthic foraminifera (Ammonia tepida), PLoS ONE, 12, e0177604., https://doi.org/10.1371/journal.pone.0177604, 2017.

Linke, P. and Lutze, G. F.: Microhabitat preferences of benthic foraminifera - a static concept or a dynamic adaptation to optimize food acquisition?, Mar. Micropaleontol., 20, 215-234, https://doi.org/10.1016/0377-8398(93)90034-U, 1993.

Metzger, E., Langlet, D., Viollier, E., Koron, N., Riedel, B., Stachowitsch, M., Faganeli, J., Tharaud, M., Geslin, E., and Jorissen, F.: Artificially induced migration of redox layers in a coastal sediment from the Northern Adriatic, Biogeosciences, 11, 2211 2224, https://doi.org/10.5194/bg-11-2211-2014, 2014.

Miller, A. A. L., Scott, D. B., and Medioli, F. S.: Elphidium excavatum (Terquem); ecophenotypic versus subspecific variation, J. Foraminifer. Res., 12, 116-144, https://doi.org/10.2113/gsjfr.12.2.116, 1982.

Moodley, L. and Hess, C.: Tolerance of Infaunal Benthic Foraminifera for Low and High Oxygen Concentrations, Biol. Bull., 183, 94-98, https://doi.org/10.2307/1542410, 1992.

Moodley, L., van der Zwaan, G. J., Herman, P. M. J., Kempers, L., and van Breugel, P.: Differential response of benthic meiofauna to anoxia with special reference to Foraminifera (Protista: Sarcodina), Mar. Ecol. Prog. Ser., 158, 151-163, https://doi.org/10.3354/meps 158151, 1997.

Moodley, L., van der Zwaan, G. J., Rutten, G. M. W., Boom, R. C. E., and Kempers, A. J.: Subsurface activity of benthic foraminifera in relation to porewater oxygen content: laboratory experiments, Mar. Micropaleontol., 34, 91-106, https://doi.org/10.1016/S0377-8398(97)00044-3, 1998a.

Moodley, L., Schaub, B. E. M., van der Zwaan, G. J., and Herman, P. M. J.: Tolerance of benthic foraminifera (Protista: Sarcodina) to hydrogen sulphide, Mar. Ecol. Prog. Ser., 169, 77-86, https://doi.org/10.3354/meps 169077, 1998b. 
Moodley, L., Boschker, H. T. S., Middelburg, J. J., Pel, R., Herman, P. M. J., de Deckere, E., and Heip, C. H. R.: Ecological significance of benthic foraminifera: 13C labelling experiments, Mar. Ecol. Prog. Ser., 202, 289-295, https://doi.org/10.3354/meps202289, 2000.

Muller, W. A.: Competition for food and other niche-related studies of three species of salt-marsh foraminifera, Mar. Biol., 31, 339351, https://doi.org/10.1007/BF00392091, 1975.

Murray, J. W.: Production in benthic foraminiferids, J. Nat. Hist., 1, 61-68, https://doi.org/10.1080/00222936700770631, 1967.

Murray, J. W.: Population dynamics of benthic foraminifera; results from the Exe Estuary, England, J. Foraminifer. Res., 13, 1-12, https://doi.org/10.2113/gsjfr.13.1.1, 1983.

Murray, J. W.: Distribution and population dynamics of benthic foraminifera from the southern North Sea, J. Foraminifer. Res., 22, 114-128, https://doi.org/10.2113/gsjfr.22.2.114, 1992.

Murray, J. W. and Alve, E.: Major aspects of foraminiferal variability (standing crop and biomass) on a monthly scale in an intertidal zone, J. Foraminifer. Res., 30, 177-191, https://doi.org/10.2113/0300177, 2000.

Nardelli, M. P., Barras, C., Metzger, E., Mouret, A., Filipsson, H. L., Jorissen, F., and Geslin, E.: Experimental evidence for foraminiferal calcification under anoxia, Biogeosciences, 11, 4029-4038, https://doi.org/10.5194/bg-11-4029-2014, 2014.

Nicholls, P. and Kim, J. K.: Sulphide as an inhibitor and electron donor for the cytochrome c oxidase system, Can. J. Biochem., 60, 613-623, https://doi.org/10.1139/o82-076, 1982.

Nomaki, H., Chikaraishi, Y., Tsuchiya, M., Toyofuku, T., Ohkouchi, N., Uematsu, K., Tame, A., and Kitazato, H.: Nitrate uptake by foraminifera and use in conjunction with endobionts under anoxic conditions, Limnol. Oceanogr., 59, 1879-1888, https://doi.org/10.4319/lo.2014.59.6.1879, 2014.

Nomaki, H., Bernhard, J. M., Ishida, A., Tsuchiya, M., Uematsu, K., Tame, A., Kitahashi, T., Takahata, N., Sano, Y., and Toyofuku, T.: Intracellular Isotope Localization in Ammonia sp. (Foraminifera) of Oxygen-Depleted Environments: Results of Nitrate and Sulfate Labeling Experiments, Front. Microbiol., 7, 163, https://doi.org/10.3389/fmicb.2016.00163, 2016.

Panieri, G.: Foraminiferal response to an active methane seep environment: A case study from the Adriatic Sea, Mar. Micropaleontol., 61, 116-130, https://doi.org/10.1016/j.marmicro.2006.05.008, 2006.

Panieri, G. and Sen Gupta, B. K.: Benthic Foraminifera of the Blake Ridge hydrate mound, Western North Atlantic Ocean, Mar. Micropaleontol., 66, 91-102, https://doi.org/10.1016/j.marmicro.2007.08.002, 2008.

Papaspyrou, S., Diz, P., García-Robledo, E., Corzo, A., and Jimenez-Arias, J.-L.: Benthic foraminiferal community changes and their relationship to environmental dynamics in intertidal muddy sediments (Bay of Cádiz, SW Spain), Mar. Ecol. Prog. Ser., 490, 121-135, https://doi.org/10.3354/meps 10447, 2013.

Pillet, L., de Vargas, C., and Pawlowski, J.: Molecular Identification of Sequestered Diatom Chloroplasts and Kleptoplastidy in Foraminifera, Protist, 162, 394-404, https://doi.org/10.1016/j.protis.2010.10.001, 2011.

Piña-Ochoa, E., Koho, K. A., Geslin, E., and Risgaard-Petersen, N.: Survival and life strategy of the foraminiferan Globobulimina turgida through nitrate storage and denitrification, Mar.
Ecol. Prog. Ser., 417, 39-49, https://doi.org/10.3354/meps08805, 2010a.

Piña-Ochoa, E., Høgslund, S., Geslin, E., Cedhagen, T., Revsbech, N. P., Nielsen, L. P., Schweizer, M., Jorissen, F., Rysgaard, S., and Risgaard-Petersen, N.: Widespread occurrence of nitrate storage and denitrification among Foraminifera and Gromiida, P. Natl. Acad. Sci. USA, 107, 1148-1153, https://doi.org/10.1073/pnas.0908440107, 2010b.

Polovodova, I., Nikulina, A., Schönfeld, J., and Dullo, W.C.: Recent benthic foraminifera in the Flensburg Fjord (Western Baltic Sea), J. Micropalaeontol., 28, 131-142, https://doi.org/10.1144/jm.28.2.131, 2009.

Pucci, F., Geslin, E., Barras, C., Morigi, C., Sabbatini, A., Negri, A., and Jorissen, F. J.: Survival of benthic foraminifera under hypoxic conditions: Results of an experimental study using the CellTracker Green method, Mar. Pollut. Bull., 59, 336-351, https://doi.org/10.1016/j.marpolbul.2009.08.015, 2009.

Rabalais, N. N., Díaz, R. J., Levin, L. A., Turner, R. E., Gilbert, D., and Zhang, J.: Dynamics and distribution of natural and human-caused hypoxia, Biogeosciences, 7, 585-619, https://doi.org/10.5194/bg-7-585-2010, 2010.

Richirt, J., Schweizer, M., Bouchet, V. M. P., Mouret, A., Quinchard, S., and Jorissen, F. J.: Morphological distinction of three Ammonia phylotypes occurring along european coasts, J. Foraminifer. Res., 49, 77-94, 2019.

Riedel, B., Diaz, R., Rosenberg, R., and Stachowitsch, M.: The ecological consequences of marine hypoxia: from behavioural to ecosystem responses, in: Stressors in the marine environment: physiological responses and ecological implication, edited by: Solan. M. and Whiteley, N. M., Oxford University Press, 175194, 2016.

Risgaard-Petersen, N., Langezaal, A. M., Ingvardsen, S., Schmid, M. C., Jetten, M. S. M., Camp, H. J. M. O. den, Derksen, J. W. M., Piña-Ochoa, E., Eriksson, S. P., Nielsen, L. P., Revsbech, N. P., Cedhagen, T., and van der Zwaan, G. J.: Evidence for complete denitrification in a benthic foraminifer, Nature, 443, 93-96, https://doi.org/10.1038/nature05070, 2006.

Roberts, A., Austin, W., Evans, K., Bird, C., Schweizer, M., and Darling, K.: A New Integrated Approach to Taxonomy: The Fusion of Molecular and Morphological Systematics with Type Material in Benthic Foraminifera, PLOS ONE, 11, e0158754, https://doi.org/10.1371/journal.pone.0158754, 2016.

Ross, B. J. and Hallock, P.: Dormancy in the Foraminifera: A Review, J. Foraminifer. Res., 46, 358-368, https://doi.org/10.2113/gsjfr.46.4.358, 2016.

Schneider, C. A., Rasband, W. S., and Eliceiri, K. W.: NIH Image to ImageJ: 25 years of image analysis, Nat. Methods, 9, 671-675, https://doi.org/10.1038/nmeth.2089, 2012.

Schönfeld, J. and Numberger, L.: Seasonal dynamics and decadal changes of benthic foraminiferal assemblages in the western Baltic Sea (NW Europe), J. Micropalaeontol., 26, 47-60, https://doi.org/10.1144/jm.26.1.47, 2007.

Seitaj, D., Schauer, R., Sulu-Gambari, F., Hidalgo-Martinez, S., Malkin, S. Y., Burdorf, L. D. W., Slomp, C. P., and Meysman, F. J. R.: Cable bacteria generate a firewall against euxinia in seasonally hypoxic basins, P. Natl. Acad. Sci. USA, 112, 13278-13283, https://doi.org/10.1073/pnas.1510152112, 2015.

Seitaj, D., Sulu-Gambari, F., Burdorf, L. D. W., RomeroRamirez, A., Maire, O., Malkin, S. Y., Slomp, C. P., and 
Meysman, F. J. R.: Sedimentary oxygen dynamics in a seasonally hypoxic basin, Limnol. Oceanogr., 62, 452-473, https://doi.org/10.1002/1no.10434, 2017.

Stramma, L., Oschlies, A., and Schmidtko, S.: Mismatch between observed and modeled trends in dissolved upper-ocean oxygen over the last $50 \mathrm{yr}$, Biogeosciences, 9, 4045-4057, https://doi.org/10.5194/bg-9-4045-2012, 2012.

Suhr, S. B., Pond, D. W., Gooday, A. J., and Smith, C. R.: Selective feeding by benthic foraminifera on phytodetritus on the western Antarctic Peninsula shelf: evidence from fatty acid biomarker analysis, Mar. Ecol. Prog. Ser., 262, 153-162, https://doi.org/10.3354/meps262153, 2003.

Sulu-Gambari, F., Seitaj, D., Meysman, F. J. R., Schauer, R., Polerecky, L., and Slomp, C. P.: Cable Bacteria Control Iron-Phosphorus Dynamics in Sediments of a Coastal Hypoxic Basin, Environ. Sci. Technol., 50, 1227-1233, https://doi.org/10.1021/acs.est.5b04369, 2016a.

Sulu-Gambari, F., Seitaj, D., Behrends, T., Banerjee, D., Meysman, F. J. R., and Slomp, C. P.: Impact of cable bacteria on sedimentary iron and manganese dynamics in a seasonallyhypoxic marine basin, Geochim. Cosmochim. Ac., 192, 49-69, https://doi.org/10.1016/j.gca.2016.07.028, 2016b.
Walton, W. R.: Techniques for recognition of living foraminifera, Contrib. Cushman Found. Foraminifer. Res., 3, 56-60, 1952.

Wang, F. and Chapman, P. M.: Biological implications of sulfide in sediment - a review focusing on sediment toxicity, Environ. Toxicol. Chem., 18, 2526-2532, https://doi.org/10.1002/etc.5620181120, 1999.

Wetsteijn, L. P. M. J.: Grevelingenmeer: meer kwetsbaar? Een beschrijving van de ecologische ontwikkelingen voor de periode 1999 t/m 2008-2010 in vergelijking met de periode $1990 \mathrm{t} / \mathrm{m}$ 1998, RWS Waterdienst, Lelystad 2011, 2011.

Woulds, C., Cowie, G. L., Levin, L. A., Andersson, J. H., Middelburg, J. J., Vandewiele, S., Lamont, P. A., Larkin, K. E., Gooday, A. J., Schumacher, S., Whitcraft, C., Jeffreys, R. M., and Schwartz, M.: Oxygen as a control on sea floor biological communities and their roles in sedimentary carbon cycling, Limnol. Oceanogr., 52, 1698-1709, https://doi.org/10.4319/lo.2007.52.4.1698, 2007. 